\title{
Enhanced magnetization of the Marlboro Clay as a product of soil pyrogenesis at the Paleocene-Eocene boundary?
}

\author{
Dennis V. Kent ${ }^{\mathrm{a}, \mathrm{b}, *}$, Luca Lanci ${ }^{\mathrm{c}}$, Huapei Wang ${ }^{\mathrm{d}}$, James D. Wright ${ }^{\mathrm{a}}$ \\ a Earth and Planetary Sciences, Rutgers University, Piscataway, NJ 08854, USA \\ ${ }^{\mathrm{b}}$ Lamont-Doherty Earth Observatory of Columbia University, Palisades, NY 10964, USA \\ c Department of Pure and Applied Science, University of Urbino “Carlo Bò”, Via S. Chiara 27, I-61029 Urbino (PU), Italy \\ d Planetary Science Institute, School of Earth Sciences, China University of Geosciences, 388 Lumo Road, Wuhan, Hubei 430074, PR China
}

\section{A R T I C L E I N F O}

\section{Article history:}

Received 6 January 2017

Received in revised form 23 April 2017

Accepted 6 June 2017

Available online 29 June 2017

Editor: H. Stoll

\section{Keywords:}

PETM

CIE

magnetic nanoparticles

single domain

soil pyrogenesis

impact fireball

\begin{abstract}
A B S T R A C T
The kaolinite-rich Marlboro Clay was deposited on the inner shelf in the Salisbury Embayment of the U.S. Atlantic margin at the onset of the carbon isotope excursion marking the 56 Ma PaleoceneEocene boundary and is characterized by an anomalously high concentration of magnetic nanoparticles of enigmatic origin that give rise to notably intense bulk magnetization. Recent studies point to a magnetic assemblage that is dominated by single-domain magnetite particles that tend to be isolated rather than arranged in chains, the most distinguishing feature of magnetotactic bacteria fossils. On the other hand, it is very unlikely that the nanoparticles can be condensates of an impact plume given the meter-scale thickness of the Marlboro Clay. We obtained new data from a landward proximal site at Wilson Lake on the New Jersey Coastal Plain and find that the abrupt increase in magnetite nanoparticles is virtually coincident stratigraphically with the recently reported impact spherule layer at the base of the Marlboro Clay in the same core. Yet the high field magnetic susceptibility, a measure of total iron concentration, and strontium isotope values on bulk sediment, an indicator of sediment weathering provenance, are not different in the Marlboro Clay from the immediately underlying Vincentown Formation. We suggest that the distinctive magnetic properties of the Marlboro Clay originated from pyromagnetic soil enhancement by widespread wildfires on the adjoining drainage area. The pyrogenetic products were soon washed from the denuded landscape and rapidly deposited as mud-waves across the shelf, becoming the Marlboro Clay. A few percent of incinerated biomass ends up as calcite known as wood ash stone and can inherit its light carbon isotope composition. Disseminated wood ash stone entrained in the Marlboro Clay could contribute to the landward increase in amplitude of the carbon isotope excursion in bulk carbonate data. A plausible trigger for the initial conflagration is a fireball from the impact of a sizable extraterrestrial object at moderate range.
\end{abstract}

(c) 2017 Elsevier B.V. All rights reserved.

\section{Introduction}

Expanded marine sections across the carbon isotope excursion (CIE) and the associated Paleocene-Eocene thermal maximum (PETM), manifestations of a massive perturbation of the global carbon cycle that were first identified in deep-sea sediments at ODP Site 690 (Kennett and Stott, 1991) and soon observed in continental sediments in Wyoming (Koch et al., 1992) (see review by McInerney and Wing, 2011), are preserved on the continental margin of Eastern North America (Cramer et al., 1999; Gibson et al., 1993) and helped inspire the current phase of the New Jersey Coastal Plain Drilling Project (Miller et al., 1997). High-

\footnotetext{
* Corresponding author.

E-mail address: dvk@rutgers.edu (D.V. Kent).
}

resolution stable isotope studies of the proximal Wilson Lake site (Miller et al., 2017) and the somewhat deeper water Millville site (Sugarman et al., 2005) showed that the onset of the CIE was recorded over a meter or more of section but may have been extremely rapid, occurring on a time scale of a decade or less (Wright and Schaller, 2013). This interpretation has not been without dispute. However, the discovery in the Wilson Lake and Millville paleo-shelf sites (as well as in the deep-sea Site 1051) of a thin layer with microtektites at the base of the Marlboro Clay, the lithostratigraphic unit on the Atlantic Coastal Plain in which the CIE is effectively recorded, provides strong supportive evidence for a fast trigger for its onset by way of an extraterrestrial impact (Schaller et al., 2016). This new evidence motivates a reappraisal of the origin of the Marlboro Clay and es- 


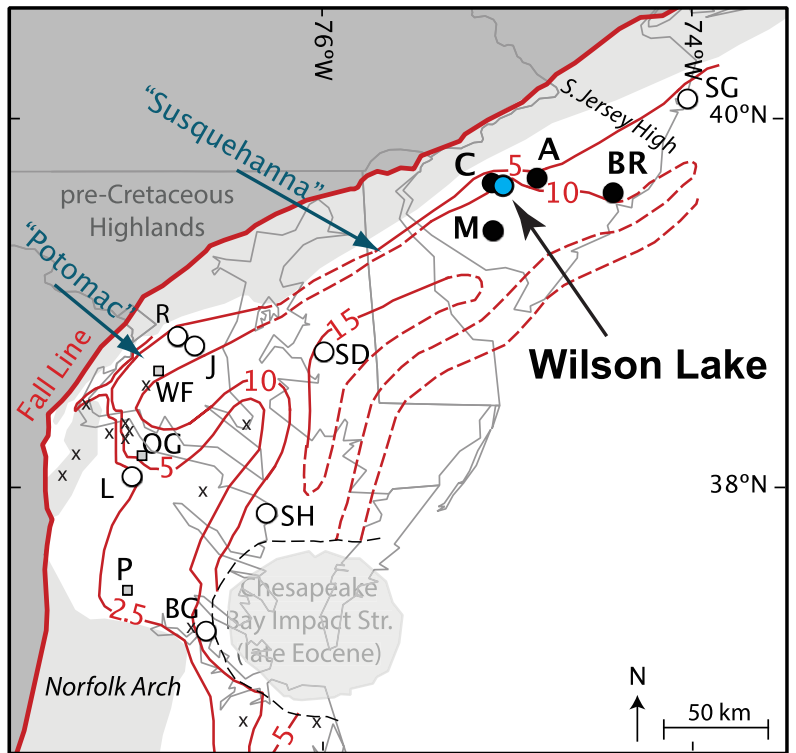

Fig. 1. Locations of key core sites (filled circles) in the vicinity of Wilson Lake (A \& $B)$ that penetrated the Marlboro Clay in the northern Salisbury Embayment and discussed in text: A, Ancora; BR, Bass River; C, Clayton; M, Millville. Contoured thickness of Marlboro Clay and locations of other core sites from Kopp et al. (2009). The Clayton and Wilson Lake core sites represent the more proximal shelf facies in relatively shallow paleowater depths $(<50 \mathrm{~m})$, the Ancora and Millville sites represent moderate paleowater depths ( $\sim 50$ to $100 \mathrm{~m}$ ), whereas the Bass River site is representative of a more distal shelf facies in deeper paleowater depths $(\sim 100 \mathrm{~m})$ (Harris et al., 2010).

pecially its distinctive magnetic properties (Kent et al., 2003a; Kopp et al., 2007), and is the aim of this study.

The Marlboro Clay (formerly the lower Manasquan Formation) is widespread in the subsurface of the Salisbury Embayment of the Atlantic Coastal Plain thickening in places to around 15 meters seaward from its coastal onlap (Fig. 1). The basal contact of the kaolinite-rich unit with the Vincentown (New Jersey) or Aquia Formation (Maryland and Virginia) (Gibson et al., 2000) closely corresponds to the onset of the CIE at the 56 Ma PaleoceneEocene boundary (Cramer et al., 1999). The Marlboro Clay is also characterized by an anomalously high concentration of single domain (SD) magnetite nanoparticles (generally less than $\sim 100 \mathrm{~nm}$ ), exceptional for a shelf deposit (Lanci et al., 2002). The high SDdominated magnetizations show an increasing landward gradient across the coastal plain of New Jersey (Kent et al., 2003a; Lippert and Zachos, 2007) and extend along-strike into Maryland and Virginia, making the Marlboro Clay a contender for the thickest SD-magnetite dominated sedimentary unit in the world (Kopp et al., 2009) despite its close proximity to sources of clastic sediment.

The magnetite nanoparticles were initially (Lanci et al., 2002) and subsequently by others (e.g., Kopp et al., 2009; Lippert and Zachos, 2007) interpreted to be predominantly bacterial magnetofossils. Magnetosome chains, the most diagnostic property of magnetotactic bacteria (MTB) (Kopp and Kirschvink, 2008), have been observed in transmission electron microscope (TEM) images made on magnetic extracts from the Marlboro Clay (e.g., Kopp et al., 2009; Lippert and Zachos, 2007). However, the extraction efficiency for a widely used procedure was reported to be only a few percent on these clays (Wang et al., 2013) so it is unclear how representative the TEM evidence is. Moreover, results from thermal fluctuation tomography (TFT; Jackson et al., 2006) on bulk samples of Marlboro Clay showed little indication of the grain size and shape distribution expected for magnetosome chains (Wang et al., 2013). Ferromagnetic resonance (FMR) is another technique thought to be sensitive to MTB (Kopp et al., 2007) but samples of Marlboro Clay turn out to have almost identical FMR characteristics as Martian meteorite ALH84001 (Wang et al., 2013). Initial enthusiasm for SD magnetite crystals in ALH84001 as evidence of MTB magnetosomes (Thomas-Keprta et al., 2000) was eventually tempered by the absence of confirming evidence of chains (Weiss et al., 2004). It thus appears that FMR and most other magnetic techniques like hysteresis properties and firstorder reversal curves (FORCs) (Egli et al., 2010) can indeed distinguish the presence of SD grains but not whether they are aligned in chains. Imaging of bulk samples of Marlboro Clay using ultrahigh-resolution, synchrotron-based, full-field transmission X-ray microscopy (Wang et al. (2015) was only able to confirm the presence of giant biogenic magnetofossils (Kopp et al., 2009; Schumann et al., 2008) but whose estimated total magnetic contribution is only $\sim 10 \%$ of bulk sediment. In any case, recent work has shown that giant magnetofossils can be found before and after the CIE and may have a rather widespread geographic, environmental, and temporal distribution (Chang et al., 2012).

More speculatively, the magnetic nanoparticles in the Marlboro Clay, by analogy with iron-rich nanoparticles reported in some Cretaceous-Paleogene boundary clays (Wdowiak et al., 2001), were suggested to represent condensates from an otherwise cryptic impact plume (Kent et al., 2003a). An impact dust protolith for the Marlboro Clay could help explain the otherwise puzzling increased concentration of the SD particles toward the landward source of a presumed dust blanket. However, there has long been a serious difficulty with the impact scenario in accounting for the meter-scale thickness of the highly magnetic kaolinitic clays in the Marlboro as condensate and ejecta fallout when such fine-grained (distal) deposits generally amount to a only few centimeters for even major impacts (Collins et al., 2005).

Investigations described here that bear on the enigmatic origin of the SD particles and enhanced magnetization of the Marlboro Clay were motivated by the reported presence of glassy spherules (microtektites) of impact origin in a discrete layer at the base of the Marlboro Clay, close to the onset of the CIE, in several core sites on the eastern margin of North America (Schaller et al., 2016). This finding relieves the burden on the magnetic nanoparticles as direct evidence of an impact but they still require a satisfactory explanation. We focused on the record from the most landward site with impact spherules, at Wilson Lake B (Fig. 1), where a $\sim 14.5 \mathrm{~m}$ thick section of the Marlboro Clay was recovered (Miller et al., 2017) and the onset of the CIE determined from detailed stable isotope stratigraphy (Wright and Schaller, 2013).

\section{Wilson Lake records of CIE}

Building on lithologic, biostratigraphic and magnetic studies of the Clayton core (Gibson et al., 2000; Kent et al., 2003a), the nearby Wilson Lake A core provided comprehensive stratigraphic series of dominant lithology, stable (carbon and oxygen) isotope ratios of bulk sediment carbonate and specimens of various benthic and planktonic foraminifera taxa, and magnetic properties across the onset of the CIE (John et al., 2008; Lippert and Zachos, 2007; Zachos et al., 2006). Detailed carbon isotope analyses on bulk carbonate (Wright and Schaller, 2013) followed on the parallel Wilson Lake B core (Fig. 2). The Wilson Lake A and B cores can be precisely correlated; for example, the steep gradient in decreasing $\delta^{13} \mathrm{C}$ bulk carbonate values at a depth ID of $366^{\prime}(\sim 111.5 \mathrm{~m})$ in Wilson Lake B corresponds to that at $360^{\prime}(\sim 110 \mathrm{~m})$ in Wilson Lake A, demarcating the onset of the CIE. It should be noted that carbon isotope values $\left(\delta^{13} \mathrm{C}\right)$ for foraminifera, especially near-surface dwelling planktonics, tend to be higher than for bulk sediment in the Marlboro Clay, a point we will return to below. At the CIE onset level in each core, the sediment magnetizations - saturation magnetization $\left(M_{S}\right)$ for Wilson Lake A (Lippert and Zachos, 2007) and 


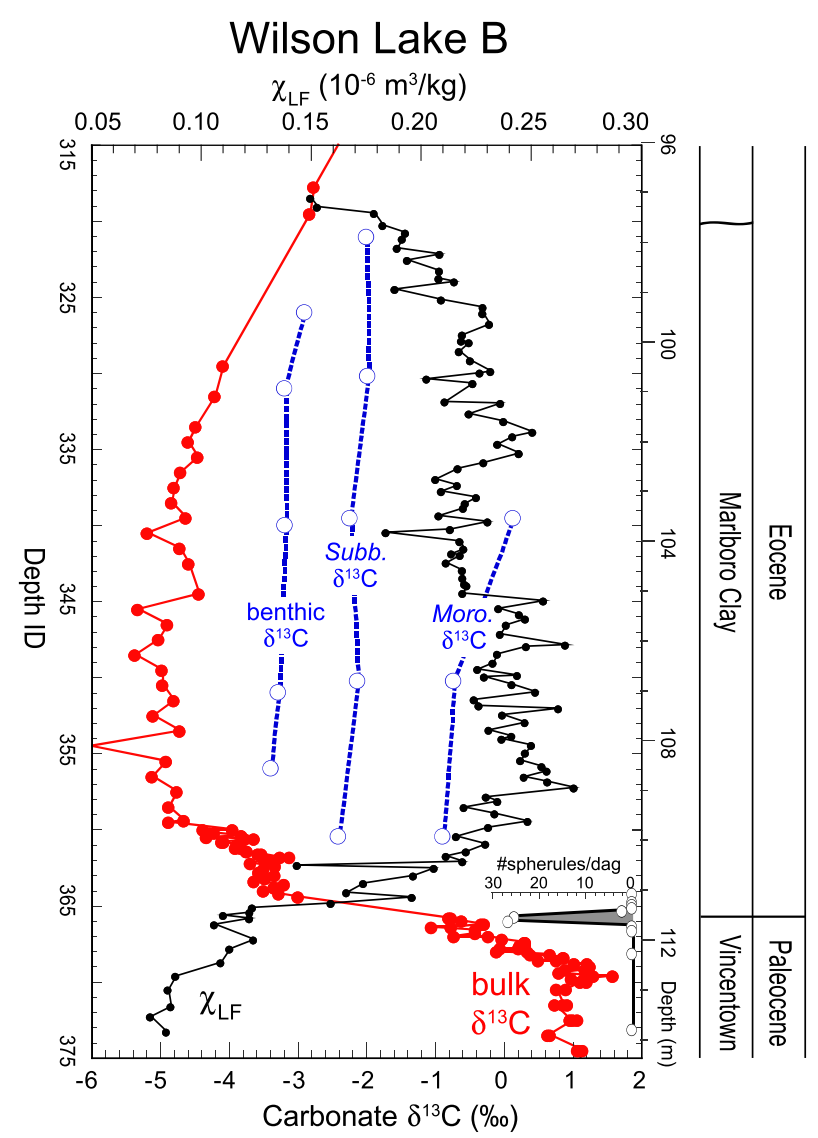

Fig. 2. Stratigraphic logs for Wilson Lake B core showing bulk sediment carbonate $\delta^{13} \mathrm{C}$ (Wright and Schaller, 2013), impact spherule abundances (\#spherules/dag = number of spherules per dacagram; Schaller et al., 2016), low-field magnetic susceptibility $\left(\chi_{L F}\right)$, and single-specimen $\delta^{13} \mathrm{C}$ values for benthic foraminifera Anomalisa (similar habitat as for Cibicidoides reported for Wilson Lake A; Lippert and Zachos, 2007), and thermocline-dwelling (Subbotina) and shallow water dwelling (Morozovella, similar habitat as for Acarina reported for Wilson Lake A; Lippert and Zachos, 2007) planktonic foraminifera. Depth ID for samples is in feet and was converted to metric units for core depth. Paleocene-Eocene boundary is placed at steepest gradient in $\delta^{13} \mathrm{C}$, which closely corresponds to the impact spherule layer at the contact between the Vincentown and Marlboro Formations.

low-field magnetic susceptibility $\left(\chi_{L F}\right)$ plotted in Fig. 2 for Wilson Lake B with other parameters described below - increase markedly upward at the base of the Marlboro Clay, as found in other core sites on the New Jersey Coastal Plain (Kent et al., 2003a).

Magnetic hysteresis parameters have been used to characterize the dominant domain state of the magnetic carriers across the Vincentown-Marlboro contact (Kent et al., 2003a; Kopp et al., 2009; Lippert and Zachos, 2007) (Fig. 3a). In particular, a Day plot (Day et al., 1977) of the ratio of saturation remanence to saturation magnetization $\left(M_{r} / M_{S}\right)$ versus the ratio of remanent coercivity to coercivity $\left(B_{c r} / B_{c}\right)$ can be used to gauge mixtures of SD and multidomain (MD) endmembers (Fig. 3b). The volume-weighted SD fraction (f_SD) was quantified from hysteresis data from Wilson Lake B samples using the mixing model of Dunlop (2002) (Table S1). Values of f_SD average only $\sim 0.06$ in the upper Vincentown Formation, indicating the dominance of coarser detrital MD grains. The average f_SD increases to 0.62 in the Marlboro Clay, quantifying the predominance of SD grains contributing to the high magnetization of this unit. Essentially the same magnetic hysteresis properties were reported for the Wilson Lake A core (Lippert and Zachos, 2007).

Evidence of an appreciable fraction of SD grains in sediments is often attributed to MTB. This is the case of the Marlboro Clay in Wilson Lake A where magnetic hysteresis data are supported
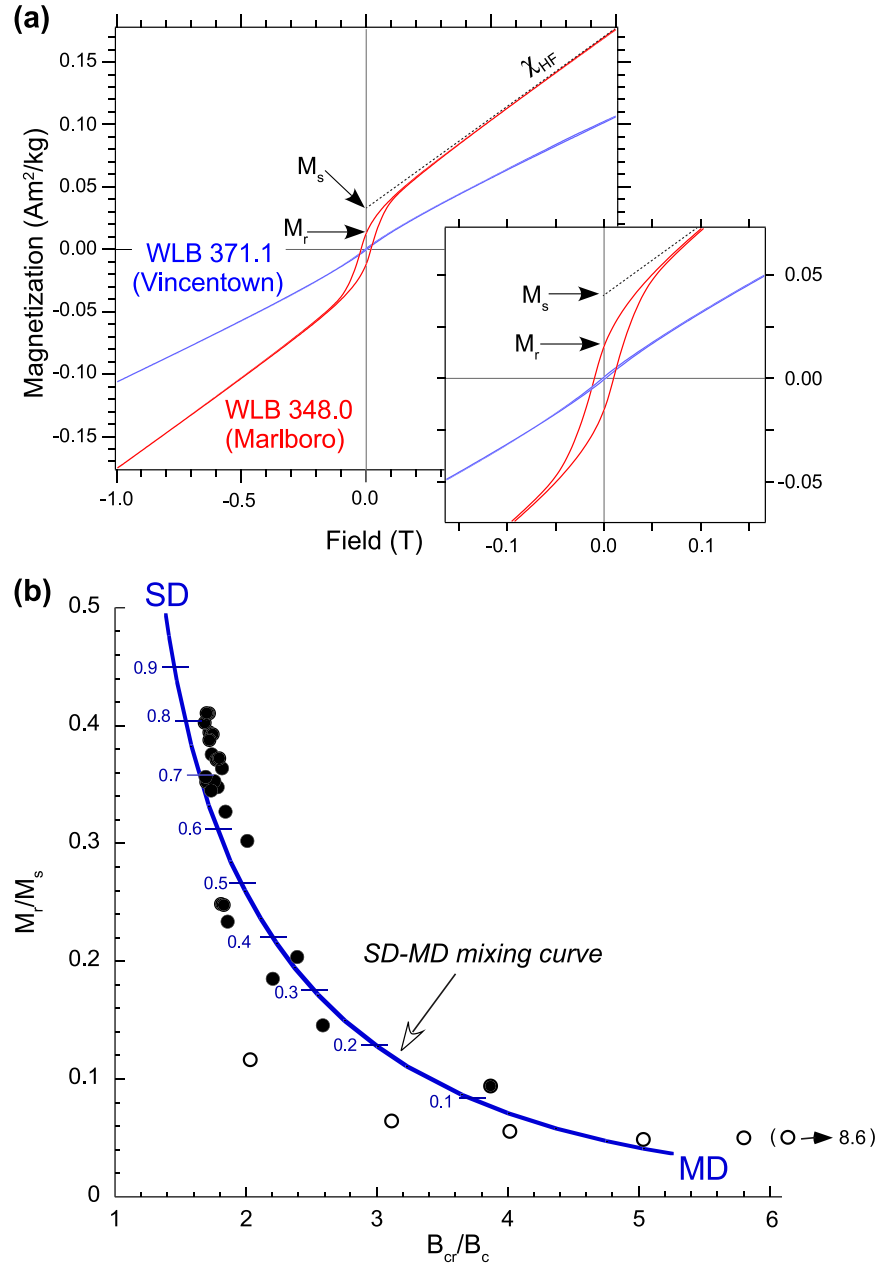

Fig. 3. (a) Examples of magnetic hysteresis loops showing the contrast in behavior between the Vincentown Formation (sample WLB 371.1) and Marlboro Clay (sample WLB 348.0). Data were produced using a Micromag AGFM Model 2900 cycling to fields up to $1 \mathrm{~T}$ on sample chips weighing $50-100 \mathrm{mg}$. The slope of magnetization versus field between 0.7 and $1.0 \mathrm{~T}$ is the high field magnetic susceptibility $\left(\chi_{H F}\right)$, which is shown by a dashed line (visible only for WLB 371.1) projected to the zero field intercept, which is the saturation magnetization, $M_{s}$, whereas $M_{r}$ is the remanent magnetization. To minimize bias from any higher coercivity phases, we used the "approach to saturation" method (Fabian, 2006) in our computation of $\chi_{H F} . M_{r}$ and $M_{S}$ are more than an order of magnitude higher, whereas $\chi_{H F}$ is only about 50\% higher, for WLB 348.0 than for WLB 371.1. (b) Day plot (Day et al., 1977) of hysteresis parameters $M_{r} / M_{s}$ versus $B_{c r} / B_{c}$ for samples from Wilson Lake B. Mixing curve between single domain (SD) and multidomain (MD) endmembers is curve 3 from Dunlop (2002). Numbers along curve are calculated volume-weighted SD fractions (f_SD). $M_{r} / M_{S}$ was used to estimate fraction of SD contribution for each sample. See notes to Table S1 for more details.

by TEM images on magnetic extracts showing what are clearly chains and therefore most probably of MTB origin (Fig. 4 in Lippert and Zachos, 2007). The efficiency of the magnetic extraction procedure is unfortunately rarely provided but we contend is an important issue in the interpretation. In a study on the Marlboro Clay from another site, a commonly used magnetic finger extraction procedure (Kopp et al., 2009; Petersen et al., 1986) was performed with a peristaltic pump circulation system using a very slow flow rate for over $24 \mathrm{~h}$ (Wang et al., 2013). Despite the deliberate care, only a small fraction of the magnetic particles was extracted based on comparing the maximum remanence determined from isothermal remanent magnetization (IRM) acquisition curves on the extract ( $\sim 5 \%$ of initial bulk value) and on the residue ( $\sim 94 \%$ of initial bulk value). The fraction of MTB particles in the limited extract itself may not be very high, judging by the slightly elevated Verwey transition at $\sim 110 \mathrm{~K}$ for the ex- 

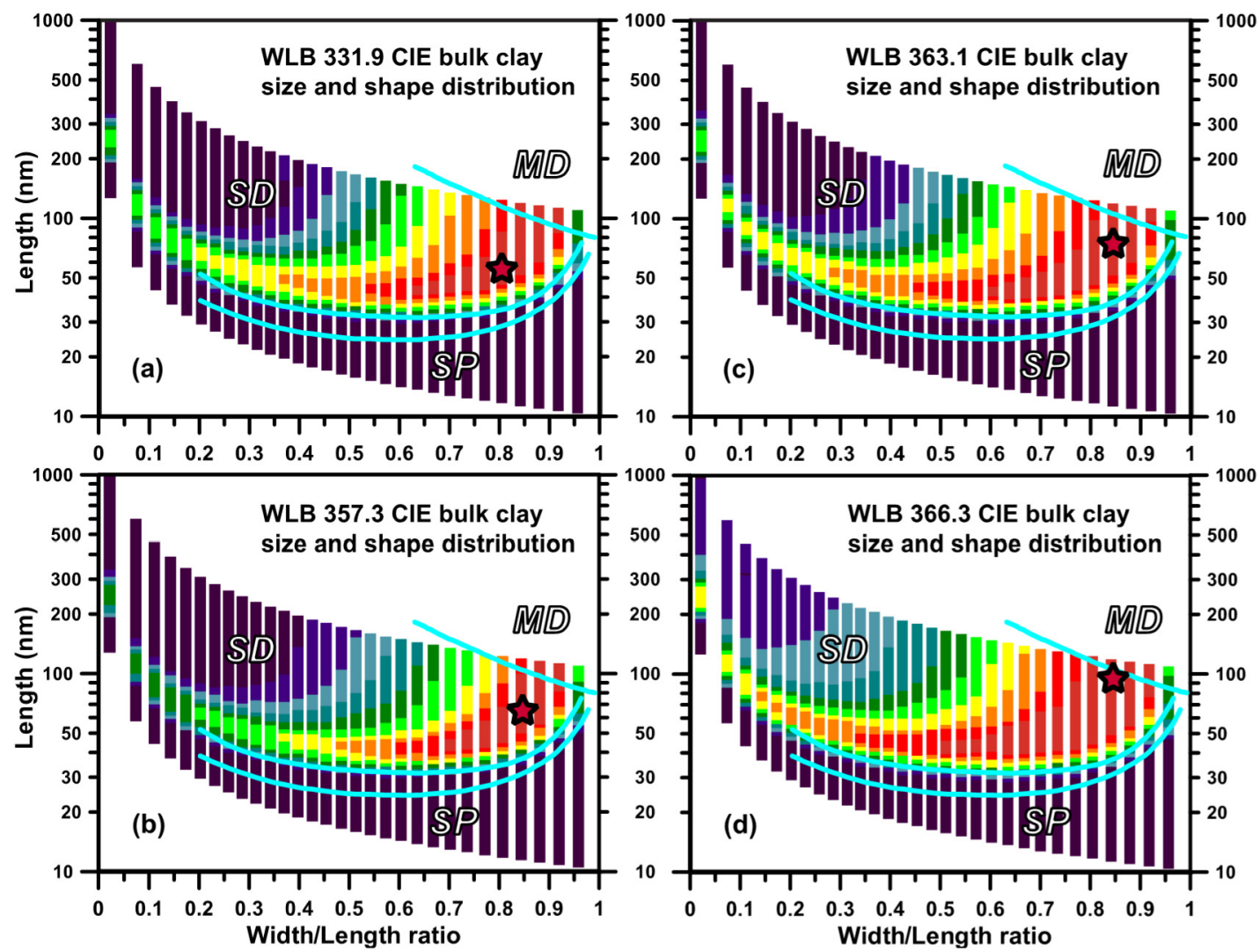

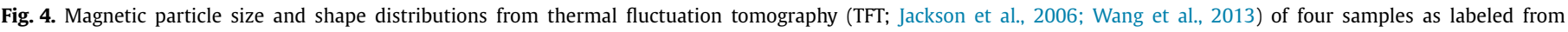

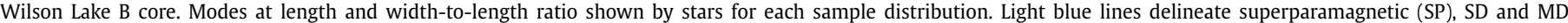
regions in this parameter space (Butler and Banerjee, 1975). Sample WLB 357.3 (Fig. 4b) was replotted from the supporting information in Wang et al. (2013).

tract compared to $100 \mathrm{~K}$ that is more typical of the stricter stoichiometry and purity associated with biomineralized magnetite, such as in MV-1 (Chang et al., 2016; Moskowitz et al., 1993; Wang et al., 2013).

In an effort to distinguish between a predominance of SD particles that are isolated versus arranged in chains in the bulk sediment, we subjected four samples from the Marlboro Clay from Wilson Lake B to high-temperature TFT experiments (Jackson et al., 2006) using the same procedures as described by Wang et al. (2013). Measurements were made on $\sim 40 \mathrm{mg}$ chips of bulk sediment using a Princeton Measurements Corporation vibrating sample magnetometer equipped with a high temperature furnace (HT-VSM) at the Institute for Rock Magnetism at the University of Minnesota. We measured back-field demagnetization curves at logarithmic increments from $2 \mathrm{mT}$ to $450 \mathrm{mT}$ for 39 points from $300 \mathrm{~K}$ to $640 \mathrm{~K}$ in a helium atmosphere to forestall alteration. The entire run of one set of TFT measurements takes about $5 \mathrm{~h}$. The TFT technique allows us to characterize the dominant width-tolength ratio of the SD particle population, which should approach 1 for isolated equidimensional grains and be much less than 1 , depending on the effective elongations, for particles in chains.

The TFT particle size and shape distributions for the Marlboro Clay samples (Fig. 4) typically show modes at a length from 60 to $90 \mathrm{~nm}$ and a width-to-length ratio between 0.8 and 0.9 . These results are very similar to those obtained from another cored section (Ancora) of the Marlboro Clay, which are distinguishable from a freeze-dried sample of a cultured strain of MTB (MV-1) that produce magnetosome chains and used as a control (Wang et al., 2013) and more consistent with the predominance of isolated near-equidimensional SD grains. Nevertheless, we acknowledge that as recently emphasized by Till et al. (2017) in a study of alternative modes of producing SD magnetite in sediments, intact chain structures remain the only reliable distinguishing feature of fossil magnetosomes, and these are best confirmed by TEM imaging (Heslop et al., 2014). Much higher extraction efficiencies that can yield a more representative fraction of the magnetic mineralogy will thus be required to more fully characterize the SD particles in the Marlboro Clay. Selective chemical extraction methods in combination with high-resolution FORC measurements (Ludwig et al., 2013) may also provide insights into the overall iron-bearing mineralogy.

A broad constraint on the relative abundance of iron-bearing minerals comes from a profile of high-field magnetic susceptibility $\left(\chi_{H F}\right)$ across the contact of the Vincentown and Marlboro Formations at Wilson Lake $B$. Where the ferrimagnetic concentration is low compared to the paramagnetic contribution to susceptibility, as is typically the case in sediments, this hysteresis parameter (Fig. 3a) is mainly related to iron content (Belley et al., 2009). In the $\sim 9 \mathrm{~m}$ section straddling the Vincentown-Marlboro contact (Fig. 5), the average $\chi_{H F}$ is $0.16 \pm 0.02(1 \sigma) \times 10^{-6} \mathrm{~m}^{3} / \mathrm{kg}$ for the Vincentown samples $(n=10)$ and $0.18 \pm 0.06 \times 10^{-6} \mathrm{~m}^{3} / \mathrm{kg}$ for the Marlboro Clay samples $(n=25)$ (Table S1). In other words, $\chi_{H F}$ hardly differs from the Vincentown to the Marlboro even though their magnetizations $\left(M_{r}, M_{s}\right.$, IRM) differ by more than an order of magnitude. Within this stratigraphic interval, the highest $\chi_{H F}\left(0.21 \times 10^{-6} \mathrm{~m}^{3} / \mathrm{kg}\right)$ actually occurs in the uppermost Vincentown (sample WLB 367.3, $111.95 \mathrm{~m}$ depth) and the marginally lowest $\chi_{H F}\left(0.12 \times 10^{-6} \mathrm{~m}^{3} / \mathrm{kg}\right)$ occurs in the lowermost Marlboro (sample WLB 364.5, $111.10 \mathrm{~m}$ depth) where IRM and $M_{r} / M_{S}$ are already increasing. This may point to post-depositional iron mobility (dissolution in lowest Marlboro, precipitation in uppermost Vincentown) across the onset of the CIE in this core. In any case, because the magnetic susceptibility of iron-bearing clays and other silicates is orders of magnitude less than that of magnetite (e.g., 


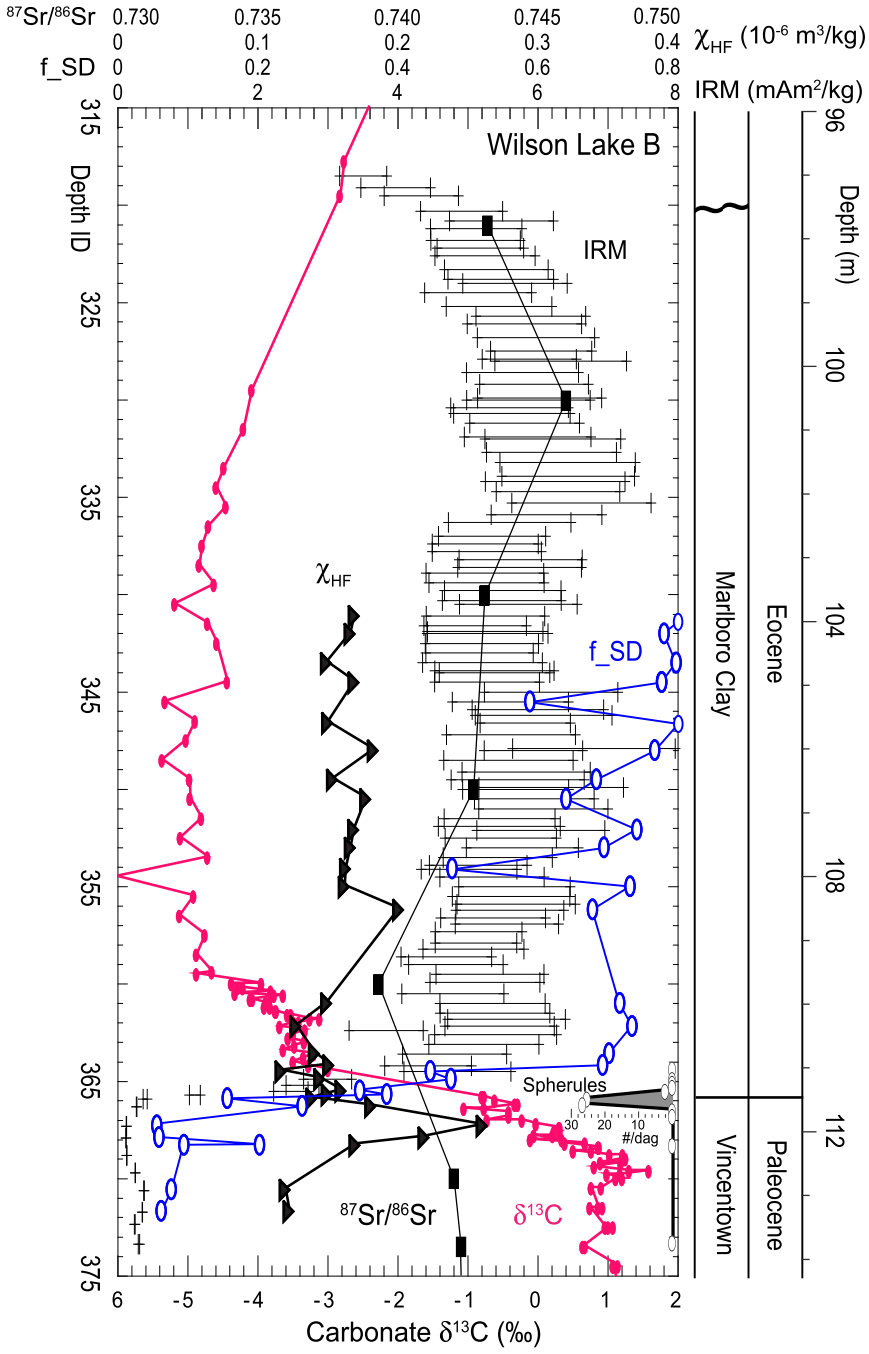

Fig. 5. Stratigraphic plots of magnetic parameters compared to impact spherule abundances (\#spherules/dag = number of spherules per dacagram; Schaller et al., 2016) and bulk sediment carbonate carbon isotope values (Wright and Schaller, 2013) in Wilson Lake B. An ASC Model IM-10-30 impulse magnetizer was used to give each $\sim 10 \mathrm{~g}$ sample an isothermal remanent magnetization (IRM) in a direct field of $1 \mathrm{~T}$ along the vertical core axis and then along the horizontal bedding plane; IRMv-h shows the range of IRM measured in each sample from the vertical (v) direction to the always higher horizontal bedding $(\mathrm{h})$ direction. $\chi_{H F}$ is high-field magnetic susceptibility and $\mathrm{f}$-SD is volume-weighted SD fraction of the total magnetization based on the SD-MD mixing curve shown in Fig. 3b (see also Table S1). The ${ }^{87} \mathrm{Sr} /{ }^{86} \mathrm{Sr}$ ratios of bulk sediment are also plotted, with five samples from the Marlboro Clay giving an average value of $0.7429 \pm 0.0024(1 \sigma)$ whereas six samples in the Vincentown Formation (four data that are below lower limit of the graph are not plotted) give practically the same average value of $0.7415 \pm 0.0031$ Table S2

Fig. 6b in Hrouda and Kahan, 1991), only an exceedingly small fraction of the iron would need to be converted to magnetite (or maghemite) to account for the high ferrimagnetism of the Marlboro Clay.

To further gauge any distinguishable difference in provenance between the Vincentown and Marlboro formations, we measured ${ }^{87} \mathrm{Sr} /{ }^{86} \mathrm{Sr}$ ratios in a set of samples across the contact of the units Table S2.

As with the broadly similar $\chi_{H F}$ values in the Vincentown and Marlboro formations, there is also no anomalous signature in Sr-isotope values across the contact (see Fig. 5). Bulk sediment ${ }^{87} \mathrm{Sr} /{ }^{86} \mathrm{Sr}$ ratios for 5 samples between WLB 320 and WLB 360 in the Marlboro Clay average $0.7429 \pm 0.0024(1 \sigma)$ whereas 6 samples between WLB 370 and WLB 384.5 in the Vincentown Formation give practically the same average value of $0.7415 \pm 0.0031$. The
${ }^{87} \mathrm{Sr} /{ }^{86} \mathrm{Sr}$ ratios are not only homogeneous but also very radiogenic. The geographic distribution of ${ }^{87} \mathrm{Sr} /{ }^{86} \mathrm{Sr}$ ratios in the dissolved load of North American rivers (Veizer, 1989) shows that the Hudson Bay region has the highest and closest to our values.

\section{Soil pyromagnetic enhancement}

Within sampling resolution, the abrupt increase in magnetization and its SD character coincide with the impact spherule layer (Schaller et al., 2016) at the base of the Marlboro Clay in the Wilson Lake B core (Fig. 5). Indeed, the SD magnetic properties across the onset of the CIE in cores from the New Jersey Coastal Plain had been speculated to be a direct product of the impact of a comet (Kent et al., 2003a). However, the new evidence from the $\chi_{H F}$ and strontium isotope data shows that the Marlboro Clay does not have an exotic gross composition, making it highly unlikely that impact plume condensates played a meaningful role in the origin of the clays or the SD particles.

More conventional interpretations of the SD particles call for the sudden proliferation of MTB starting at the onset of the CIE at the base of the Marlboro Clay and continuing over the depositional range of the unit. There is direct evidence diagnostic of magnetosome chains in the Marlboro Clay from TEM observations. However, as discussed above, it is unclear to what extent chains are representative of the total magnetic mineralogy of the Marlboro Clay with some evidence suggesting they may be present in only minor background concentrations. To the degree that the SD-rich character of the Marlboro Clay is related to a uniformitarian depositional regime, the difficulty of finding modern analogues (Dickens and Francis, 2003; Kent et al., 2003b), and the uniqueness of the Marlboro Clay in the entire Late Cretaceous and Cenozoic Atlantic Coastal Plain section in which there are no reported SDrich counterparts (Lanci et al., 2002), for example, during the Early Eocene climatic optimum (Kopp et al., 2009), further make the MTB hypothesis problematical as largely responsible for the distinctive bulk magnetization of the Marlboro Clay.

The close stratigraphic coincidence between the profound changes in magnetization at the inception of Marlboro Clay deposition and the impact spherule layer nonetheless suggests there could be causal relationship. The possibility we consider is that an impact triggered wildfires that promoted pyrogenic mineral transformations in soils, including the enhancement of mineral magnetic properties. Whether triggered directly by an impact fireball or sparked by massive lightning storms over a well-kindled landscape, wildfires and soil pyrogenesis may be a plausible alternate source of the SD particles entrained in the Marlboro Clay.

The classic experimental work by Le Borgne (1960), regarded as one of the earliest contributions to environmental magnetism (Oldfield and Crowther, 2007), described marked increases in $\chi_{L F}$ in a variety of soils heated under various conditions in the laboratory. In a typical laboratory experiment, the magnetic susceptibility would start to increase after heating to around $300^{\circ} \mathrm{C}$ and become higher by several orders of magnitude by $500-600^{\circ} \mathrm{C}$. Most of the magnetic enhancement occurred by heating in a reducing atmosphere, as in the presence of organics, and cooling in an oxidizing environment, conditions that might actually resemble those in a wildfire. These early laboratory findings are supported by systematic changes observed in the magnetization of soils after natural burns (Clement et al., 2011). The documented pyromagnetic enhancements point to conversions of or within iron-bearing clays and other minerals to strongly magnetic phases like magnetite or maghemite typically in the ultrafine grain size range (Humphreys et al., 2003; Longworth et al., 1979; Rummery et al., 1979).

We did a few simple laboratory-heating experiments on available samples of the non-marine Woodbridge Clay of the 


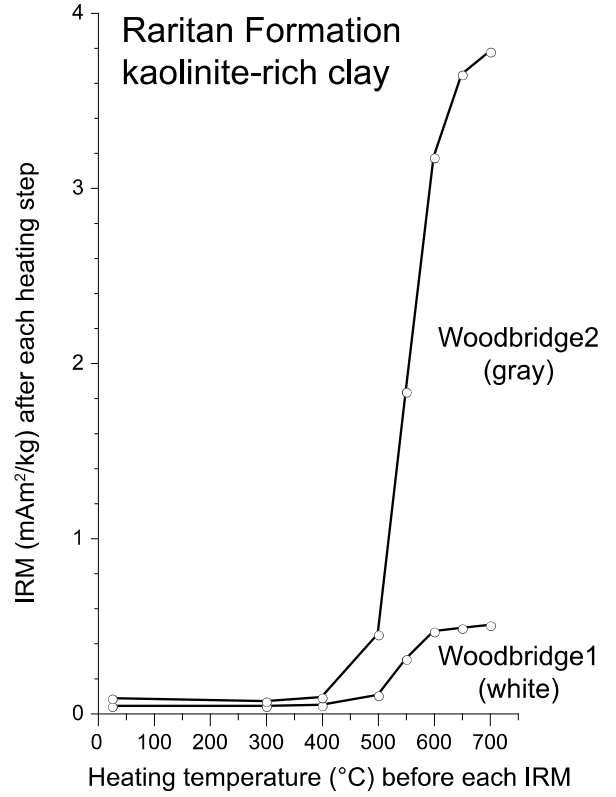

Fig. 6. Examples of changes in IRM produced after step heating (each for $45 \mathrm{~min}$. in air) of two samples of the non-marine Woodbridge Clay Member of the Cenomanian-age Raritan Formation collected from exposures in a former clay pit at Sayreville, NJ (Owens and Sohl, 1969). The sample labeled Woodbridge 1 was white and presumably has a higher kaolinite concentration than gray-colored sample Woodbridge2.

Cenomanian-age Raritan Formation that had been collected from exposures in a former clay pit at Sayreville, NJ. The kaolinite content of the Woodbridge Clay, a potential analogue of sediment sources for the Marlboro Clay, can reach 90\% (Owens and Sohl, 1969) but the unit was dismissed as a possible source of reworked material for the Marlboro on account of the its weak magnetization and low (<0.05) $M_{r} / M_{s}$ hysteresis ratios (Kent et al., 2003a). Intriguingly, IRMs produced after progressive step heating show an increase by an order of magnitude by $600^{\circ} \mathrm{C}$ in a white, presumably more pure kaolinite sample, and by more than a factor of 40 in a gray, less pure kaolinite sample (Fig. 6). In fact, the gray sample attains an IRM magnitude of $\sim 4 \mathrm{mAm}^{2} / \mathrm{kg}$ and a remarkably high $M_{r} / M_{s}$ ratio of 0.38 , comparable to those measured in the Marlboro Clay and which indicate that much of the newly-created pyromagnetic phase was in the stable SD size range.

The limited experiments on the Woodbridge Clay samples are only suggestive because it is unclear how their lithologies and the conditions of heating in the laboratory correspond to the pyrogenesis of the soils that became the protolith of the Marlboro Clay. For example, Till et al. (2015) point out that several studies of soil pyromagnetic enhancement have identified goethite, a common constituent of soils, as the iron-bearing parent phase whose transformation at temperatures as low as $210^{\circ} \mathrm{C}$ produces strongly magnetic nanoparticles (e.g., Clement et al., 2011; Till et al., 2017). Whatever the original magnetic mineralogy, a case can be advanced that a substantial fraction of the protolith of the Marlboro Clay already experienced pyrogenesis whereas that of the Vincentown Formation did not. This comes from a comparison of IRM acquisition curves before and after step heating to $650^{\circ} \mathrm{C}$ for samples from both units. The sample from the Marlboro Clay (WLB 361.0, Fig. 7a) has nearly the same IRM back-field demagnetization curves produced before and after heating to $650{ }^{\circ} \mathrm{C}$ (in air, as for all the heating experiments) - there is only about a $10 \%$ increase in the maximum IRM due mostly to a high coercivity phase. On the other hand, the sample from the Vincentown Formation (WLB 371.7, Fig. 7b) shows a factor of five increase in magnitude of the maximum IRM and a large increase in the re-
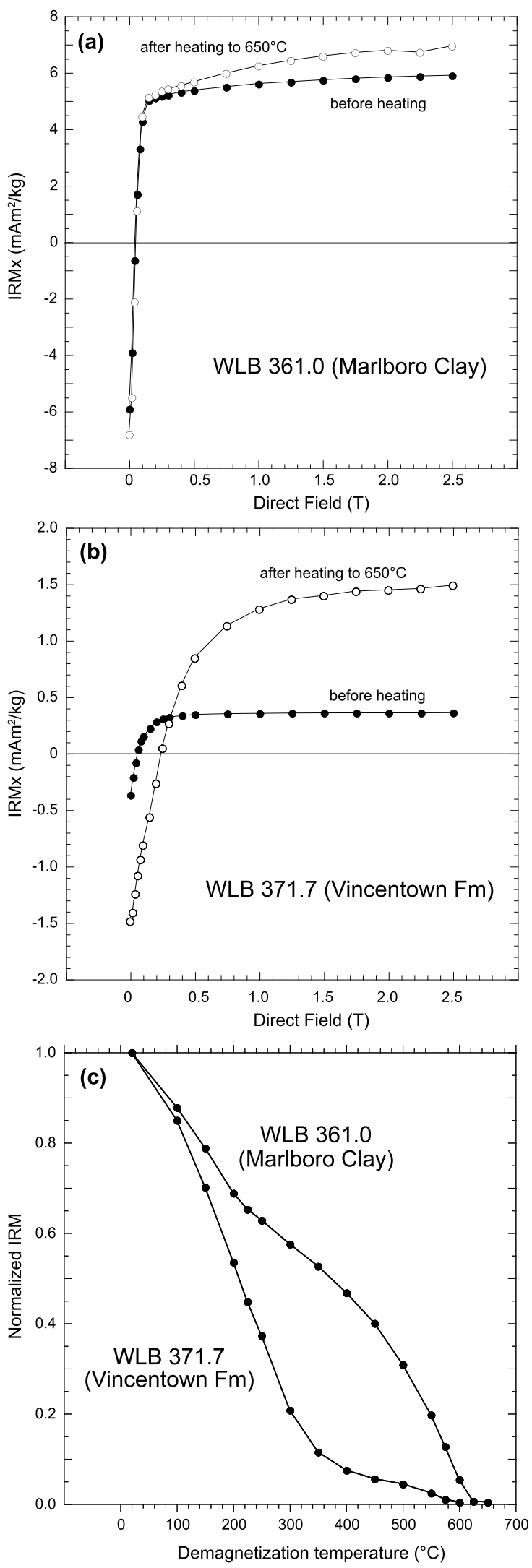

Fig. 7. Comparison of IRM backfield demagnetization curves before and after heating to $650^{\circ} \mathrm{C}$ for (a) a sample from the Marlboro Clay (WLB 361.0) and (b) a sample from the underlying Vincentown Formation (WLB 371.7). (c) Thermal demagnetization of the initial (room temperature) maximum IRM for the samples from the Marlboro Clay (WLB 361.0) and the Vincentown Formation (WLB 371.7). 
manent coercivity after heating. Thermal unblocking spectra of the initial IRMs are also noticeably different (Fig. 7c). The Marlboro Clay sample (WLB 361.0) has a dominant phase that continues to unblock just above $600^{\circ} \mathrm{C}$, perhaps attributable to maghemite; there is also an inflection in the demagnetization curve at around $200^{\circ} \mathrm{C}$, which could correspond to feroxyhyte, a magnetic mineral with the same composition as goethite but which is a ferrite with a Curie temperature of around $180^{\circ} \mathrm{C}$ (Harrison and Feinberg, 2009; Koch et al., 1995). In contrast, thermal demagnetization of the initial IRM for the Vincentown sample (WLB 371.7) shows a dominant phase that unblocks at $\sim 350^{\circ} \mathrm{C}$, probably the sulfide greigite, and a subsidiary phase that unblocks at $\sim 580^{\circ} \mathrm{C}$ and is thus most likely magnetite (Harrison and Feinberg, 2009).

The degree and amount of soil pyrogenesis would depend on poorly known factors like soil type, sources of fuels, duration and temperatures of the wildfires and how widespread they may have been; an exploration of a few relevant parameters is discussed in SI.1. In short, a wildfire producing a surface temperature of $700^{\circ}$ would need to burn for eight hours to allow $30 \%$ of that temperature $\left(210^{\circ} \mathrm{C}\right)$, about the minimum required to consume organic matter and begin to promote pyrogenetic mineral transformations including enhancement of magnetization, to penetrate $\sim 20 \mathrm{~cm}$. It so happens (SI.1) that around $20 \mathrm{~cm}$ of magnetically enhanced soil would need to be denuded from the drainage basin and deposited on the shelf as the most uniformly magnetic facies of the Marlboro Clay.

\section{Deposition of the Marlboro Clay}

Denudation of the landscape by wildfires would have made the exposed magnetically enhanced soils subject to intense erosion and rapid transport to the shelf environment, especially if there was rapid climatic warming from injection of water vapor into the atmosphere from an oceanic splashdown (Joshi et al., 2017). High runoff into the Salisbury Embayment is suggested by the high kaolinite contents (Gibson et al., 2000) with the TEX 86 and $\delta^{18} \mathrm{O}$ record of the Marlboro Clay indicating an increase in temperature and a decrease in salinity due to increased precipitation (Cramer et al., 1999; Makarova et al., 2017; Self-Trail et al., 2012; Sluijs et al., 2007). A large supply of riverine sediment shown to produce mudflows during major floods or storms in a variety of settings (Geyer et al., 2000; Goff et al., 2013) may have characterized the paleo-Susquehanna and/or paleo-Potomac drainages during deposition of the Marlboro Clay, especially under the extreme climate conditions that are believed to have prevailed at the onset of the CIE. A dense cross-shelf instrument array off the Eel River in northern California documents an example of modern episodic mid-shelf mud deposition and suggests that waveinduced processes play an important role redistributing riverine sediment, especially as cross-shelf flows of fluidized mud (Traykovski et al., 2000). Lithologic banding at the Wilson Creek and Millville sites in New Jersey (Wright and Schaller, 2013) and the presence of hundreds of individual depositional packages that may represent wave-enhanced sediment flows at localities such as Mattawoman Creek, Maryland (Powars et al., 2015) point to very rapid accumulation of the Marlboro Clay.

High sediment accumulation rates could not be sustained for very long in the limited accommodation space of a shallow-water shelf setting but this may help explain why Marlboro Clay sections are invariably truncated by an erosional unconformity, including at Wilson Lake (Lippert and Zachos, 2007; Miller et al., 2017; Wright and Schaller, 2013). We also discovered that magnetizations of the Marlboro Clay are very anisotropic: IRM induced in the horizontal bedding plane is about 35\% higher than along the vertical axis in the Marlboro Clay but is more typically only about $5 \%$ higher in the Vincentown Formation (Fig. 5, Table S1). The high anisotropy of the
Marlboro Clay is consistent with its fine-grained composition and concomitant high compaction potential as a fluidized mudflow.

\section{Carbon isotopic signals in the Marlboro Clay}

The stable isotope record from Wilson Lake (A and B cores) is rather unusual: the largest negative carbon isotope excursion occurs in the benthic foraminifera (Cibicidoides or Anomalinoides) with smaller amplitudes in the thermocline dwelling (Subbotina) and especially the surface-water dwelling (Acarina or Morozovella) planktonic foraminifera in Wilson Lake A (Zachos et al., 2006). Although with less detail, the same pattern is found in Wilson Lake B (Fig. 2). This is opposite to the pattern consistently seen in more open-ocean sites, like the classic single-specimen foraminifera records from ODP Site 690 (Thomas et al., 2002). Those records invariably show progressively smaller carbon isotope anomalies in deeper dwelling foraminifera, a pattern interpreted as due to the downward propagation of an isotopically light carbon atmospheric signal. Bulk carbonate measurements from open ocean sites are usually dominated by near-surface dwelling (photosynthesizing) nannofossils (Shackleton, 1985). However, in the Wilson Lake A and B cores, the carbon isotope values of bulk carbonate (basically the fine fraction) more closely resemble those of the benthic rather than planktonic foraminifera.

A novel potential source of isotopically light carbon is woodash stone from the same conflagration that produced the magnetically enhanced soil. Burned wood yields roughly $0.5-2 \%$ by weight as ash (Misra et al., 1993) of which nearly $1 / 2$ can be carbonate (wood-ash stone; Ulery et al., 1993) having a carbon isotope composition comparable to the incinerated organics of around $-25 \% 0{ }^{13} \mathrm{C}$ (Shahack-Gross and Ayalon, 2013). Although wood-ash stone might constitute only a small fraction of the carbonate in the Marlboro Clay on average, a proximal site like Wilson Lake may have incorporated a higher portion of the light carbon $\delta^{13} \mathrm{C}$ from the wood-ash stone. At more distal sites like Bass River (Fig. 1), the $\delta^{13} \mathrm{C}$ of bulk sediment carbonate decreases to around $-3 \%$ in the CIE (compared to around $-5 \%$ at Wilson Lake; Fig. 2) and Wright and Schaller (2013) report $\mathbf{- 8 \%}$ for bulk sediments at the more shoreward Medford outcrop. The difference in the $\delta^{13} \mathrm{C}$ of bulk sediment carbonate can be explained by a more diluted wood-ash stone contribution at Bass River compared to Wilson Lake. The increase in the amplitude of the CIE with decreasing water depth and closer proximity to the paleoshore was attributed to a relatively larger atmospheric contribution to a wedging marine carbon pool (Wright and Schaller, 2013). Interestingly, $\delta^{13} \mathrm{C}$ of benthic foraminifera (Cibicidoides) as well as thermocline dwelling planktonic foraminifera (Subbotina) track the bulk sediment $\delta^{13} \mathrm{C}$ changes at Bass River, Wilson Lake A (John et al., 2008; Makarova et al., 2017) and Millville (Makarova et al., 2017) indicating a bottom-up pattern in $\delta^{13} \mathrm{C}$ of foraminifera. This pattern may have been amplified by the shoreward concentration gradient of organic carbon and/or disseminated wood-ash stone derived from the adjoining land areas.

\section{Discussion and conclusions}

We suggest that the documented close correspondence in Wilson Lake B of the abrupt increase in SD particles and the impact spherule layer (Schaller et al., 2016) can be best explained as resulting from the incineration of vegetation and soil organics across a wide expanse of the adjoining drainage basin by a fireball generated by an impact of appropriate size and range. Our proposed scenario of denudation of pyromagnetically enhanced soils, including wood-ash carbonate with light carbon isotope composition, and their rapid deposition in the Salisbury Embayment by masstransport processes can help account for the presence of the Marl- 
boro Clay, a thick clay-rich unit deposited across the shelf with remarkably high concentrations of SD magnetic particles. An upper size limit of what become the SD particles may be dictated by the clay lattices in which they apparently crystallized during pyrogenesis; the paucity of finer-grained superparamagnetic particles may in part reflect grain-size dependent processes like selective diagenesis related to their greater specific surface area for chemical reactions during transport of the magnetic assemblage from the terrestrial to marine environment.

Iron dissolution/precipitation indicated by the $\chi_{H F}$ data across the Vincentown-Marlboro contact in Wilson Lake B is a warning that there might be mobility (diagenesis) of phases carrying the carbon and oxygen isotope records. Carbonate diagenesis could help explain the puzzling $\sim 1.2 \mathrm{~m}$ offset between the apparent onset of the decrease in bulk sediment carbonate $\delta^{13} \mathrm{C}(\sim$ sample WLB 370) and that of the increase in IRM ( sample WLB 366), which closely corresponds to the impact spherule layer (Schaller et al., 2016) (Fig. 5). Otherwise, the bulk sediment carbonate $\delta^{13} \mathrm{C}$ signal would seem to be decoupled from a (nearly) coincidental impact event. We anticipate that foraminiferal stable isotope data will eventually resolve this issue in favor of a close relationship corrupted by diagenesis of the fine-fraction carbonates. The available foraminiferal carbon isotope data already show a relatively flat response through most of the Marlboro Clay (Fig. 2), consistent with very rapid deposition over what was most probably only an initial brief interval of the total $\sim 150 \mathrm{kyr}$ duration of the CIE (Murphy et al., 2010). The possibility of a pyrogenetic origin of some of the fine-fraction carbonate coupled with the specter of diagenesis already demand caution in the interpretation of bulk carbonate carbon and oxygen isotope data in this core as global environmental signals.

Finally, it would be ironic if the iron-rich nanoparticles inferred from Mossbauer spectroscopy in Cretaceous-Paleogene (K-Pg) boundary sediments and thought to be impact plume condensates (Verma et al., 2001; Wdowiak et al., 2001), which was the initial interpretative model for the magnetic nanoparticles at the CIE (Kent et al., 2003a), may also have originated from impacttriggered wildfires as inferred from widespread high concentrations of elemental carbon or soot (Wolbach et al., 1988, 1985). However, only rare occurrences of charcoal were found in several non-marine $\mathrm{K}-\mathrm{Pg}$ boundary sections in the midcontinent of North America, which seemed to preclude a global-scale wildfire related to the impact event (Belcher et al., 2003). An extenuating factor for the absence of charcoal may be that the studied $\mathrm{K}-\mathrm{Pg}$ boundary sections in Colorado and farther north in the U.S. and Canada are more than $2000 \mathrm{~km}$ distant from the Chicxulub impact site, perhaps far enough away that the impact fireball was below the horizon and there was no direct thermal radiation (Collins et al., 2005). Alternatively, the widespread soot distribution may be explained as due to the combustion of hydrocarbons at the Chicxulub impact site (Belcher et al., 2009; Harvey et al., 2008). The few specific charcoal results available for the CIE are even more ambiguous. High but variable concentrations of graphitic black carbon were found across the CIE interval at the Bass River site (Fig. 1) but there was no distinctive high concentration of charcoal at the CIE onset level (Moore and Kurtz, 2008). But in England there is a high abundance of charcoal in the CIE in the Cobham Lignite Bed described as unparalleled elsewhere in the Paleogene of southern England (Collinson et al., 2003). Preliminary results from microscopic black carbon shards discovered in the same cores with primary impact ejecta show exciting promise for providing more detailed evidence directly bearing on pyrogenetic effects recorded in the Marlboro Clay (Fung et al., 2016).

\section{Acknowledgements}

We thank Morgan Schaller and his group at RPI for ongoing discussions and acknowledge his lead in the transformative discovery of impact spherules at the Paleocene-Eocene boundary that motivated our reassessment of the magnetic evidence for an impact trigger for the CIE. We gratefully acknowledge the contributions of Linda Godfrey, Rick Mortlock, Jake Setera, Weimin Si, and Jill Van Tongeren for generating some of the geochemical and $\mathrm{Sr}$ isotope data from Wilson Lake B, Chris Lepre for making many of the sample magnetic measurements, ongoing discussions with Ken Miller on New Jersey Coastal Plain stratigraphy and sedimentology, and Mike Jackson for information on the literature for high field susceptibility. We are grateful to the Institute for Rock Magnetism for support of a Rock Magnetism Summer School and two Student Visiting Fellowships (to HW) that allowed the TFT measurements to be made. We greatly appreciate the critical comments of the journal reviewers (Peter Lippert, Ramon Egli, and three that are anonymous) of earlier versions of the paper that challenged us to improve it. Some of the ideas presented here were developed in preparation of a white paper with Wally Broecker for a workshop on the PETM held in January 2016 at Arizona State University. Funding for this research was pieced together from a variety of sources including support from the Rutgers University Board of Governors Professor fund and the Lamont-Doherty Incentive Account for the operations of the Paleomagnetic Labs, and the Rutgers Core Repository for curation of the Wilson Lake B core. LDEO Contribution \#8122.

\section{Appendix A. Supplementary material}

Supplementary material related to this article can be found online at http://dx.doi.org/10.1016/j.epsl.2017.06.014.

\section{References}

Belcher, C.M., Collinson, M.E., Sweet, A.R., Hildebrand, A.R., Scott, A.C., 2003. Fireball passes and nothing burns - the role of thermal radiation in the CretaceousTertiary event: evidence from the charcoal record of North America. Geology 31, 1061-1064.

Belcher, C.M., Finch, P., Collinson, M.E., Scott, A.C., Grassineau, N.V., 2009. Geochemical evidence for combustion of hydrocarbons during the K-T impact event. Proc. Natl. Acad. Sci. 106, 4112-4117.

Belley, F., Ferré, E.C., Martín-Hernández, F., Jackson, M.J., Dyar, M.D., Catlos, E.J., 2009 The magnetic properties of natural and synthetic $\left(\mathrm{Fe}_{x}, \mathrm{Mg}_{1-x}\right)^{2} \mathrm{SiO}_{4}$ olivines. Earth Planet. Sci. Lett. 284, 516-526.

Butler, R.F., Banerjee, S.K., 1975. Theoretical single-domain grain size range in magnetite and titanomagnetite. J. Geophys. Res. 80, 4049-4058.

Chang, L., Heslop, D., Roberts, A.P., Rey, D., Mohamed, K.J., 2016. Discrimination of biogenic and detrital magnetite through a double Verwey transition temperature. J. Geophys. Res. 121, 3-14.

Chang, L., Roberts, A.P., Williams, W., Gerald, J.D.F., Larrasoana, J.C., Jovane, L., Muxworthy, A.R., 2012. Giant magnetofossils and hyperthermal events. Earth Planet. Sci. Lett. 351-352, 258-269.

Clement, B.M., Javier, J., Sah, J.P., Ross, M.S., 2011. The effects of wildfires on the magnetic properties of soils in the Everglades. Earth Surf. Process. Landf. 36, 460-466.

Collins, G.S., Melosh, H.J., Marcus, R.A., 2005. Earth Impact Effects Program: a webbased computer program for calculating the regional environmental consequences of a meteoroid impact on Earth. Meteorit. Planet. Sci. 40, 817-840.

Collinson, M.E., Hooker, J.J., Gröcke, D.R., 2003. Cobham Lignite Bed and penecontemporaneous macrofloras of southern England: a record of vegetation and fire across the Paleocene-Eocene Thermal Maximum. Spec. Pap., Geol. Soc. Am. 369, 335-350.

Cramer, B.S., Aubry, M.-P., Miller, K.G., Olsson, R.K., Wright, J.D., Kent, D.V., 1999 An exceptional chronologic, isotopic, and clay mineralogic record of the latest Paleocene thermal maximum, Bass River, NJ, ODP 174AX. Bull. Soc. Géol. Fr. 170, 883-897.

Day, R., Fuller, M., Schmidt, V.A., 1977. Hysteresis properties of titanomagnetites: grain-size and compositional dependence. Phys. Earth Planet. Inter. 13, 260-267.

Dickens, G.R., Francis, J.M., 2003. Comment on "A case for a comet impact trigger for the Paleocene/Eocene thermal maximum and carbon isotope excursion" by D.V. Kent et al. Earth Planet. Sci. Lett. 217, 197-200. 
Dunlop, D.J., 2002. Theory and application of the Day plot (Mrs/Ms versus Hcr/Hc) 2. Application to data for rocks, sediments, and soils. J. Geophys. Res. 107. http://dx.doi.org/10.1029/2001JB000487.

Egli, R., Chen, A.P., Winklhofer, M., Kodama, K.P., Horng, C.-S., 2010. Detection of noninteracting single domain particles using first-order reversal curve diagrams. Geochem. Geophys. Geosyst. 11, Q01Z11. http://dx.doi.org/10.1029/ 2009GC002916.

Fabian, K., 2006. Approach to saturation analysis of hysteresis measurements in rock magnetism and evidence for stress dominated magnetic anisotropy in young mid-ocean ridge basalt. Phys. Earth Planet. Inter. 154, 299-307.

Fung, M.K., Schaller, M.F., Hoff, C.M., Katz, M.E., Wright, J.D., 2016. Widespread wildfires at the Paleocene Eocene boundary: evidence from abundant charcoal preserved in the thick Marlboro Clay. Abstr. Program - Geol. Soc. Am. 48, 192-194.

Geyer, W.R., Hill, P., Milligan, T., Traykovski, P., 2000. The structure of the Eel River plume during floods. Cont. Shelf Res. 20, 2067-2093.

Gibson, T.G., Bybell, L.M., Mason, D.B., 2000. Stratigraphic and climatic implications of clay mineral changes around the Paleocene/Eocene boundary of the northeastern US margin. Sediment. Geol. 134, 65-92.

Gibson, T.G., Bybell, L.M., Owens, J.P., 1993. Latest Paleocene lithologic and biotic events in neritic deposits of southwestern New Jersey. Paleoceanography 8 , 495-514.

Goff, J.A., Austin, J.A., Flood, R.D., Christensen, B., Browne, C.M., Saustrup, S., 2013. Rapid response survey gauges sandy's impact on seafloor. Eos 94, 337-338.

Harris, A.D., Miller, K.G., Browning, J.V., Sugarman, P.J., Olsson, R.K., Cramer, B.S., Wright, J.D., 2010. Integrated stratigraphic studies of Paleocene-lowermost Eocene sequences, New Jersey Coastal Plain: evidence for glacioeustatic control. Paleoceanography 25, PA3211.

Harrison, R.J., Feinberg, J.M., 2009. Mineral magnetism: providing new insights into geoscience processes. Elements 5, 209-215.

Harvey, M.C., Brassell, S.C., Belcher, C.M., Montanari, A., 2008. Combustion of fossil organic matter at the Cretaceous-Paleogene (K-P) boundary. Geology 36, 355-358.

Heslop, D., Roberts, A.P., Chang, L., 2014. Characterizing magnetofossils from first-order reversal curve (FORC) central ridge signatures. Geochem. Geophys. Geosyst. 15, 2170-2179.

Hrouda, F., Kahan, S., 1991. The magnetic fabric relationship between sedimentary and basement nappes in the High Tatra Mountains, N. Slovakia. J. Struct. Geol. 13, 431-442.

Humphreys, G.S., Shakesby, R.A., Doerr, S.H., Blake, W.H., Wallbrink, P., Hart, D.M., 2003. Some effects of fire on the regolith. In: Roach, I.C. (Ed.), Advances in Regolith. CRC LEME, pp. 216-220.

Jackson, M., Carter-Stiglitz, B., Egli, R., Solheid, P., 2006. Characterizing the superparamagnetic grain distribution $f(V, H k)$ by thermal fluctuation tomography. J. Geophys. Res. 111, B12S07. http://dx.doi.org/10.1029/2006JB004514.

John, C.M., Bohaty, S.M., Zachos, J.C., Sluijs, A., Gibbs, S.J., Brinkhuis, H., Bralower T.J., 2008. North American continental margin records of the Paleocene-Eocene thermal maximum: implications for global carbon and hydrological cycling. Paleoceanography 23, PA2217. http://dx.doi.org/10.1029/2007PA001465.

Joshi, M., Glasow, R.V., Smith, R.S., Paxton, C.G.M., Maycock, A.C., Lunt, D.J., Loptson, C., Markwick, P., 2017. Global warming and ocean stratification: a potential result of large extraterrestrial impacts. Geophys. Res. Lett. 44, 1-8. http://dx.doi.org/10.1002/2017GL073330.

Kennett, J.P., Stott, L.D., 1991. Abrupt deep-sea warming, palaeoceanographic changes and benthic extinctions at the end of the Palaeocene. Nature 353 225-229.

Kent, D.V., Cramer, B.S., Lanci, L., Wang, D., Wright, J.D., Van der Voo, R., 2003a. A case for a comet impact trigger for the Paleocene/Eocene thermal maximum and carbon isotope excursion. Earth Planet. Sci. Lett. 211, 13-26.

Kent, D.V., Cramer, B.S., Lanci, L., Wang, D., Wright, J.D., Van der Voo, R., 2003b. Reply to a comment on "A case for comet impact trigger for the Paleocene/Eocene thermal maximum and carbon isotope excursion" by G.R. Dickens and J.M. Francis. Earth Planet. Sci. Lett. 217, 201-205.

Koch, C.B., Oxborrow, C.A., Mørup, S., Madsen, M.B., Quinn, A.J., Coey, J.M.D., 1995 Magnetic properties of feroxyhyte $(\delta-\mathrm{FeOOH})$. Phys. Chem. Miner. 22, 333-341.

Koch, P.L., Zachos, J., Gingerich, P.D., 1992. Correlation between isotope records in marine and continental carbon reservoirs near the Palaeocene/Eocene boundary. Nature 358, 319-322.

Kopp, R.E., Kirschvink, J.L., 2008. The identification and biogeochemical interpretation of fossil magnetotactic bacteria. Earth-Sci. Rev. 86, 42-61.

Kopp, R.E., Raub, T.D., Schumann, D., Vali, H., Smirnov, A.V., Kirschvink, J.L. 2007. Magnetofossil spike during the Paleocene-Eocene thermal maximum: Ferromagnetic resonance, rock magnetic, and electron microscopy evidence from Ancora, New Jersey, United States. Paleoceanography 22, PA4103. http://dx.doi.org/10.1029/2007PA001473.

Kopp, R.E., Schumann, D., Raub, T.D., Powars, D.S., Godfrey, L.V., Swanson-Hysell, N.L., Maloof, A.C., Vali, H., 2009. An Appalachian Amazon? Magnetofossil evidence for the development of a tropical river-like system in the mid-Atlantic United States during the Paleocene-Eocene thermal maximum. Paleoceanography 24, PA4211. http://dx.doi.org/10.1029/2009PA001783.

Lanci, L., Kent, D.V., Miller, K.G., 2002. Detection of Late Cretaceous and Cenozoic sequence boundaries on the Atlantic coastal plain using core log integration of magnetic susceptibility and natural gamma ray measurements at Ancora, New Jersey. J. Geophys. Res. 107, 2216. http://dx.doi.org/10.1029/2000JB000026.

Le Borgne, E., 1960. Influence du feu sur les propriétés magnétiques du sol et sur celles du schiste et du granite. Ann. Geophys. 16, 159-195.

Lippert, P.C., Zachos, J.C., 2007. A biogenic origin for anomalous fine-grained magnetic material at the Paleocene-Eocene boundary at Wilson Lake, New Jersey. Paleoceanography 22, PA4104. http://dx.doi.org/10.1029/2007PA001471.

Longworth, G., Becker, L.W., Thompson, R., Oldfield, F., Dearing, J.A., Rummery, T.A., 1979. Mössbauer effect and magnetic studies of secondary iron oxides in soils. J. Soil Sci. 30, 93-110.

Ludwig, P., Egli, R., Bishop, S., Chernenko, V., Frederichs, T., Rugel, G., Merchel, S. 2013. Characterization of primary and secondary magnetite in marine sediment by combining chemical and magnetic unmixing techniques. Glob. Planet. Change 110, 321-339.

Makarova, M., Wright, J.D., Miller, K.G., Babila, T.L., Rosenthal, Y., Park, J.I., 2017. Hydrographic and ecologic implications of foraminiferal stable isotopic response across the U.S. mid-Atlantic continental shelf during the PaleoceneEocene Thermal Maximum. Paleoceanography 32, 1-18. http://dx.doi.org/ 10.1002/2016PA002985.

McInerney, F.A., Wing, S.L., 2011. The Paleocene-Eocene Thermal Maximum: a perturbation of carbon cycle, climate, and biosphere with implications for the future. Annu. Rev. Earth Planet. Sci. 39, 489-516.

Miller, K.G., Browning, J.V., Aubry, M.-P., Babila, T., Baluyot, R.D., EsmeraySenlet, S., Feigenson, M.D., Karakaya, S., Lombardi, C.J., Makarova, M., McCreary, S., McLaughlin, P.P., Monteverde, D.H., Olsson, R.K., Smith, C.T., Sugarman, P.J., Wright, J.D., 2017. Wilson Lake site. In: Proceedings of the Ocean Drilling Program, Initial Reports 174AX. (supplement), http:// dx.doi.org/10.14379/odp.proc.174AXS.111.2017.

Miller, K.G., Browning, J.V., Pekar, S.F., Sugarman, P.J., 1997. Cenozoic evolution of the New Jersey Coastal Plain: changes in sea level, tectonics, and sediment supply. In: Proceedings of the Ocean Drilling Program, Scientific Results 150X, pp. 361-373.

Misra, M.K., Ragland, K.W., Baker, A.J., 1993. Wood ash composition as a function of furnace temperature. Biomass Bioenergy 4, 103-116.

Moore, E.A., Kurtz, A.C., 2008. Black carbon in Paleocene-Eocene boundary sediments: a test of biomass combustion as the PETM trigger. Palaeogeogr. Palaeoclimatol. Palaeoecol. 267, 147-152.

Moskowitz, B.M., Frankel, R.B., Bazylinski, D.A., 1993. Rock magnetic criteria for the detection of biogenic magnetite. Earth Planet. Sci. Lett. 120, 283-300.

Murphy, B.H., Farley, K.A., Zachos, J.C., 2010. An extraterrestrial 3He-based timescale for the Paleocene-Eocene thermal maximum (PETM) from Walvis Ridge, IODP Site 1266. Geochim. Cosmochim. Acta 74, 5098-5108.

Oldfield, F., Crowther, J., 2007. Establishing fire incidence in temperate soils using magnetic measurements. Palaeogeogr. Palaeoclimatol. Palaeoecol. 249, 362-369.

Owens, J.P., Sohl, N.F., 1969. Shelf and deltaic paleoenvironments in the CretaceousTertiary formations of the New Jersey coastal plain. In: Subitzky, S. (Ed.), Geology of Selected Areas in New Jersey and Eastern Pennsylvania and Guidebook of Excursions. Rutgers University Press, New Brunswick, NJ, pp. 235-278.

Petersen, N., von Dobeneck, T., Vali, H., 1986. Fossil bacterial magnetite in deep-sea sediments from the South Atlantic Ocean. Nature 320, 611-615.

Powars, D.S., Edwards, L.E., Kidwell, S.M., Schindler, J.S., 2015. Cenozoic stratigraphy and structure of the Chesapeake Bay region. Geol. Soc. Am. Field Guide 40, 171-229.

Rummery, T.A., Bloemendal, J., Dearing, J., Oldfield, F., 1979. The persistence of fire-induced magnetic oxides in soils and lake sediments. Ann. Geophys. 35, 103-107.

Schaller, M.F., Fung, M.K., Wright, J.D., Katz, M.E., Kent, D.V., 2016. Impact ejecta at the Paleocene-Eocene boundary. Science 354, 225-229.

Schumann, D., Raub, T.D., Kopp, R.E., Guerquin-Kern, J.-L., Wu, T.-D., Rouiller, I., Smirnov, A.V., Sears, S.K., Lucken, U., Tikoo, S.M., Hesse, R., Kirschvink, J.L., Vali, H., 2008. Gigantism in unique biogenic magnetite at the Paleocene-Eocene Thermal Maximum. Proc. Natl. Acad. Sci. 105, 17648-17653.

Self-Trail, J.M., Powars, D.S., Watkins, D.K., Wandless, G.A., 2012. Calcareous nannofossil assemblage changes across the Paleocene-Eocene Thermal Maximum: evidence from a shelf setting. Mar. Micropaleontol. 92-93, 61-80.

Shackleton, N.J., 1985. Oceanic carbon isotope constraints on oxygen and carbon dioxide in the cenozoic atmosphere. Geophys. Monogr. 32, 412-417.

Shahack-Gross, R., Ayalon, A., 2013. Stable carbon and oxygen isotopic compositions of wood ash: an experimental study with archaeological implications. J. Archaeol. Sci. 40, 570-578.

Sluijs, A., Brinkhuis, H., Schouten, S., Bohaty, S.M., John, C.M., Zachos, J.C., Reichart, G.-J., Sinninghe Damste, J.S., Crouch, E.M., Dickens, G.R., 2007. Environmental precursors to rapid light carbon injection at the Palaeocene/Eocene boundary. Nature 450, 1218-1221.

Sugarman, P.J., Miller, K.G., Browning, J.V., McLaughlin, P.P., Brenner, G.J., Buttari, B., Cramer, B.S., Harris, A., Hernandez, J., Katz, M.E., Lettini, B., Misintseva, S., Monteverde, D.H., Olsson, R.K., Patrick, L., Roman, E., Wojtko, M.J., Aubry, M.-P., Feigenson, M.D., Barron, J.A., Curtin, S., Cobbs, G., Cobbs, G., Bukry, D., Huffman, B.A., 2005. Millville site. In: Proceedings of the Ocean Drilling Program, Initial Reports 174AX, pp. 1-94 (Supplement) 
Thomas, D.J., Zachos, J.C., Bralower, T.J., Thomas, E., Bohaty, S., 2002. Warming the fuel for the fire: evidence for the thermal dissociation of methane hydrate during the Paleocene-Eocene thermal maximum. Geology 30, 1067-1070.

Thomas-Keprta, K.L., Bazylinski, D.A., Kirschvink, J.L., Clemett, S.J., McKay, D.S., Wentworth, S.J., Vali, H., Gibson Jr., E.K., Romanek, C.S., 2000. Elongated prismatic magnetite crystals in ALH84001 carbonate globules: potential Martian magnetofossils. Geochim. Cosmochim. Acta 64, 4049-4081.

Till, J.L., Guyodo, Y., Lagroix, F., Morin, G., Menguy, N., Ona-Nguema, G., 2017. Presumed magnetic biosignatures observed in magnetite derived from abiotic reductive alteration of nanogoethite. C. R. Géosci. http://dx.doi.org/10.1016/ j.crte.2017.02.001.

Till, J.L., Guyodo, Y., Lagroix, F., Morin, G., Ona-Nguema, G., 2015. Goethite as a potential source of magnetic nanoparticles in sediments. Geology 43, 75-78.

Traykovski, P., Geyer, W.R., Irish, J.D., Lynch, J.F., 2000. The role of wave-induced density-driven fluid mud flows for cross-shelf transport on the Eel River continental shelf. Cont. Shelf Res. 20, 2113-2140.

Ulery, A.L., Graham, R.C., Amrhein, C., 1993. Wood-ash composition and soil PH following intense burning. Soil Sci. 156, 358-364.

Veizer, J., 1989. Strontium isotopes in seawater through time. Annu. Rev. Earth Planet. Sci. 17, 141-156.

Verma, H.C., Upadhyay, C., Tripathi, R.P., Tripathi, A., Shukla, A.D., Bhandari, N., 2001. Nano-sized iron phases at the $\mathrm{K} / \mathrm{T}$ and $\mathrm{P} / \mathrm{T}$ boundaries revealed by Mössbauer spectroscopy. Lunar Planet. Sci. 32, 1270.pdf.
Wang, H., Kent, D.V., Jackson, M.J., 2013. Evidence for abundant isolated magnetic nanoparticles at the Paleocene-Eocene boundary. Proc. Natl. Acad. Sci. 110, 425-430.

Wang, H., Wang, J., Chen-Wiegart, Y.-c.K., Kent, D.V., 2015. Quantified abundance of magnetofossils at the Paleocene-Eocene boundary from synchrotron-based transmission X-ray microscopy. Proc. Natl. Acad. Sci. 112, 12598-12603.

Wdowiak, T.J., Armendarez, L.P., Agresti, D.G., Wade, M.L., Wdowiak, S.Y., Claeys, P., Izett, G., 2001. Presence of an iron-rich nanophase material in the upper layer of the Cretaceous-Tertiary boundary clay. Meteorit. Planet. Sci. 36, 123-133.

Weiss, B.P., Kim, S.S., Kirschvink, J.L., Kopp, R.E., Sankaran, M., Kobayashi, A. Komeili, A., 2004. Magnetic tests for magnetosome chains in Martian meteorite ALH84001. Proc. Natl. Acad. Sci. 101, 8281-8284.

Wolbach, W.S., Gilmour, I., Anders, E., Orth, C.J., Brooks, R.R., 1988. Global fire at the Cretaceous-Tertiary boundary. Nature 334, 665-669.

Wolbach, W.S., Lewis, R.S., Anders, E., 1985. Cretaceous extinctions: evidence for wildfires and search for meteoritic material. Science 230, 167-170.

Wright, J.D., Schaller, M.F., 2013. Evidence for a rapid release of carbon at the Paleocene-Eocene Thermal Maximum. Proc. Natl. Acad. Sci. 110, 15908-15913.

Zachos, J.C., Schouten, S., Bohaty, S., Quattlebaum, T., Sluijs, A., Brinkhuis, H., Gibbs, S.J., Bralower, T.J., 2006. Extreme warming of mid-latitude coastal ocean during the Paleocene-Eocene Thermal Maximum: inferences from TEX86 and isotope data. Geology 34, 737-740. 


\title{
SUPPLEMENTARY MATERIAL
}

Soil pyrogenesis parameters, impact fireball constraints, and magnetic hysteresis and Sr-isotope data for the Paleocene-Eocene section at Wilson Lake

$$
\text { for }
$$

Enhanced magnetization of the Marlboro Clay as a product of soil pyrogenesis at the Paleocene-Eocene boundary?

\author{
Dennis V. Kent ${ }^{* 1,2}$ \\ Luca Lanci ${ }^{3}$ \\ Huapei Wang ${ }^{4}$ \\ James D. Wright ${ }^{1}$ \\ ${ }^{1}$ Earth and Planetary Sciences, Rutgers University, Piscataway, NJ 08854, USA \\ *dvk@rutgers.edu \\ ${ }^{2}$ Lamont-Doherty Earth Observatory of Columbia University, Palisades, NY 10964, USA \\ ${ }^{3}$ Department of Pure and Applied Science, University of Urbino "Carlo Bò", Via S. \\ Chiara 27, I-61029 Urbino (PU), Italy \\ ${ }^{4}$ Planetary Science Institute, School of Earth Sciences, China University of Geosciences, \\ 388 Lumo Road, Wuhan, Hubei 430074, P. R. China
}




\section{SM.1. Soil pyrogenesis parameters}

Tropical forests have a substantial areal concentration of vegetation carbon $(\sim 12$ $\left.\mathrm{GtC} / \mathrm{Mkm}^{2}\right)$, about twice as large as temperate and boreal forests $\left(\sim 6 \mathrm{GtC} / \mathrm{Mkm}^{2}\right)$ (IPCC 2000: http://www.fao.org/docrep/0hhhfssss04/y1997e/y1997e07.htm). However, the upper meter of soil in boreal forests contains such a large concentration of carbon that the total carbon stock concentration for boreal forests $\left(41 \mathrm{GtC} / \mathrm{Mkm}^{2}\right)$ is actually greater than for tropical forests $\left(24 \mathrm{GtC} / \mathrm{Mkm}^{2}\right)$ and much higher than for temperate forests $(15$ $\mathrm{GtC} / \mathrm{Mkm}^{2}$ ). We use a nominal total combustible carbon concentration of $25 \mathrm{GtC} / \mathrm{Mkm}^{2}$ for Eastern North America in the latest Paleocene. We assume that regionally extended wildfires triggered the incineration of some fraction of this vegetation and soil carbon over a drainage area of as much as $0.30 \mathrm{Mkm}^{2}$ in a topographically subdued landscape (Pazzaglia and Brandon, 1996). This drainage was the likely source of sediment for the Marlboro Clay, which with an average thickness of about $6 \mathrm{~m}$ (Kopp et al., 2009) and its most highly magnetic facies estimated to extend in a band adjacent to the paleoshore about $25 \mathrm{~km}$ wide (nominal distance across strike between Wilson Lake and Bass River sites) and $\sim 400 \mathrm{~km}$ long (i.e., an area $\sim 0.01 \mathrm{Mkm}^{2}$ ), would imply that around $0.20 \mathrm{~m}$ of magnetically enhanced soil would need to be denuded from the drainage basin and deposited on the shelf as Marlboro Clay.

In the presence of heavy fuels, as may have existed about the time of the PETM in regions bordering the North Atlantic (Collinson et al., 2003; Wing and Currano, 2013), wildfires can apparently heat the soil surface to temperatures of $700^{\circ} \mathrm{C}$ or more (Santín et al., 2016). Substantial consumption of organic matter starts around $200-250^{\circ} \mathrm{C}$ and is complete at around $460^{\circ} \mathrm{C}$ (Giovannini et al., 1988). Figure S1 shows a simple conductive heat flow model of a dimensionless temperature parameter (related to the difference between initial soil temperature and the temperature of the heated surface) as a function of depth in the soil (thermal diffusivity of $0.05 \mathrm{~m}^{2} /$ day; Farouki, 1981) over different time scales. According to this model, a wildfire producing a surface temperature of $700^{\circ} \mathrm{C}\left(\mathrm{Ts}-\mathrm{Ti}=680^{\circ} \mathrm{C}\right)$ would need to burn for around eight hours to allow $30 \%$ of that temperature $\left(\mathrm{Ts}-\mathrm{Ti}=210^{\circ} \mathrm{C}\right)$, about the minimum required to consume organic matter and begin to promote pyrogenetic mineral transformations including enhancement of magnetization (Clement et al., 2011; Humphreys et al., 2003; Le Borgne, 1960; Rummery, 1983), to penetrate $15-20 \mathrm{~cm}$ into the soil. Charcoal studies show that abrupt climate warming, for example, the last glacial-interglacial transition in North America, plays an important role in broad-scale levels of wildfires (Marlon et al., 2009) but there are few studies on soil temperature-time curves as a function of the amount and structure of fuel in modern controlled settings (Molina and Llinares, 2001) to better gauge the likely intensity and duration of wildfires at the onset of the CIE in Eastern North America. 


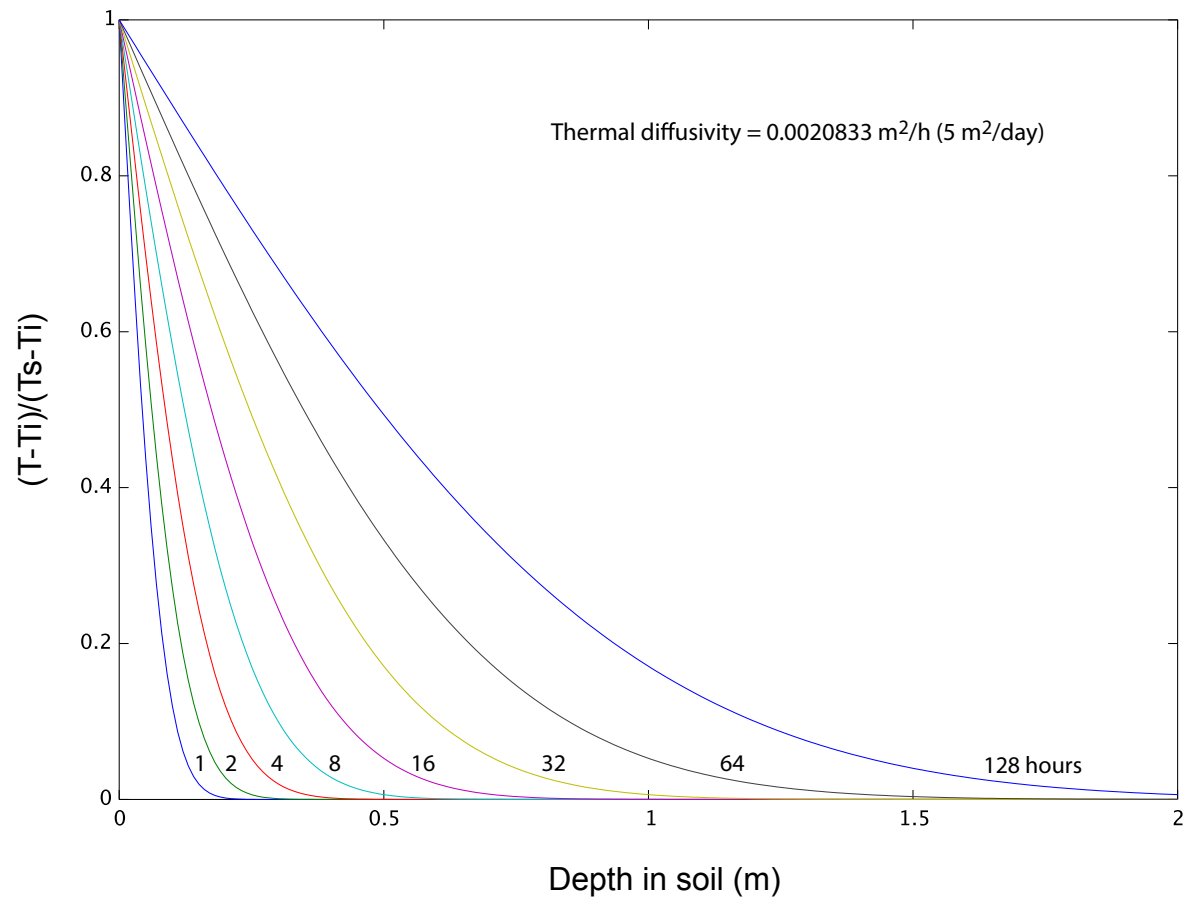

Figure S1. Temperature profiles through soil for different initial (Ti) and surface temperature (Ts) applied for different time durations. The temperature reached by the soil at depth $\mathrm{x}$ can be estimated by computing transient heat conduction in a semi-infinite solid, with the boundary condition of a constant temperature Ts on the surface, which is described by:

$$
\frac{T-T s}{T s-T i}=\operatorname{erfc}\left(\frac{x}{\sqrt{4 \alpha t}}\right)
$$

where erfc is the complementary error function, $\alpha$ is the thermal diffusivity and $t$ is time. We have computed the dimensionless temperature versus soil depth for $\alpha=0.05 \mathrm{~m}^{2} /$ day and several time spans from 1 to 128 hours. 


\section{SM.2. Impact fireball constraints}

The close coincidence of the impact spherule layer and the sharp increase in SD nanoparticles that we argue resulted mainly from soil pyrogenesis allows the speculation that an impact fireball could have triggered the initial conflagration. We thus seek to satisfy two constraints on the collateral effects of an impact as a function of its magnitude and range: mean ejecta particle diameter and thermal radiation. According to the impact model of Collins et al. (2005), for a given impact velocity (assumed to be an average of $51 \mathrm{~km} / \mathrm{s}$ for a comet), the amount of ejecta and the fragment diameter vary with bolide mass and inversely with distance from the impact site (Fig. S2). For example, a comet of $10 \mathrm{~km}$ diameter and density $1000 \mathrm{~kg} / \mathrm{m}^{3}$ impacting at the most probable angle of impact of $45^{\circ}$ in the ocean at a mean water depth $4000 \mathrm{~m}$ would produce an ejecta blanket $\sim 30$ $\mathrm{mm}$ thick with mean fragment diameter of around $0.7 \mathrm{~mm}$ arriving within 10 minutes at a range of $1250 \mathrm{~km}$. A more immediate effect would be thermal radiation from a fireball, with an estimated radiant flux more than 17 times greater than the Sun, sufficient to ignite trees. At a range of $1000 \mathrm{~km}$, the ejecta blanket would be nearly $60 \mathrm{~mm}$ thick with a mean fragment diameter of $1.27 \mathrm{~mm}$ and the fireball would have an estimated radiant flux more than 64 times greater than the Sun; however, at a range of $1500 \mathrm{~km}$, the ejecta blanket would be less than $20 \mathrm{~mm}$ thick with a mean fragment diameter of $0.43 \mathrm{~mm}$ but importantly for our scenario, the fireball would be below the horizon with no direct thermal radiation.

Comparable outcomes could be produced at greater (smaller) distances from the impact of a larger (smaller) diameter comet, all other parameters the same. For example, a $15 \mathrm{~km}$ diameter comet impact at a range of $1500 \mathrm{~km}$ would produce an ejecta blanket over $90 \mathrm{~mm}$ thick with a mean fragment diameter of $\sim 0.70 \mathrm{~mm}$, and the fireball would have an estimated radiant flux more than 31 times greater than the Sun; nevertheless, by $2000 \mathrm{~km}$ the fireball would be below the horizon with no direct thermal radiation. Impact of a $5 \mathrm{~km}$ diameter comet at a range of $750 \mathrm{~km}$ would produce less than a $20 \mathrm{~mm}$ thick ejecta blanket with mean fragment diameter of $\sim 0.46 \mathrm{~mm}$ and the fireball would ignite trees but by a range of $1250 \mathrm{~km}$, the ejecta blanket would be less than $1 \mathrm{~mm}$ and the fireball would be below the horizon with no direct thermal radiation.

The glassy spherules found thus far and identified as microtektites from Wilson Lake B, Millville and ODP Site 1051 average $\sim 300 \mu \mathrm{m}$ in diameter with modest concentrations that vary by only a factor of $\sim 2$ amongst the sites, suggesting a distal fallout and a modest-sized impact crater. The impact of a high-velocity comet with its low silicate fraction and further dilution by a high volume of crustal target rocks could help explain the small to negligible iridium anomaly at the CIE (Schmitz et al., 1997; Schmitz et al., 2004). Comets consist mostly of $\mathrm{CHO}$ volatiles with a carbon mass fraction of about 20

percent (Delsemme, 1988; Greenberg, 1998). The carbon tends to be ${ }^{13} \mathrm{C}$ deficient (Jehin 
et al., 2009; Mumma and Charnley, 2011). Spectroscopic observations of various comets from Earth give $\delta^{13} \mathrm{C}$ values ranging from -1 to $-281 \%$ with a median of $-51 \%$; direct measurements on dust particles returned from comet $81 \mathrm{P} /$ Wild2 have compatible $\delta^{13} \mathrm{C}$ values ranging from -11 to -56\% (Jehin et al., 2009) (Table S3); likewise measurements on interplanetary dust particles captured in Earth's atmosphere and thought to come from comets and have a median $\delta^{13} \mathrm{C}$ value of about $-40 \%$ (Messenger, 2000). Carbon from a comet could thus conceivably contribute directly to the carbon isotope excursion at the onset of the CIE.

For reference, some of the consequences of the impact of a comet of nominal $10 \mathrm{~km}$ diameter (density $1000 \mathrm{~kg} / \mathrm{m}^{3}, 20 \%$ carbon with $\delta^{13} \mathrm{C}-40 \%$ ) whose collision at the most probable impact velocity of $51 \mathrm{~km} / \mathrm{s}$ and impact angle of $45^{\circ}$ in the ocean of average water depth $4000 \mathrm{~m}$ would have opened a crater in the water $114 \mathrm{~km}$ in diameter and excavated a final crater in the crust with a diameter of $84 \mathrm{~km}$ extending down into the crust $1120 \mathrm{~m}$ (Collins et al., 2005). At a nominal distance of $1250 \mathrm{~km}$ (e.g., the distance from Bermuda to Newark, NJ) and using the same model parameters, Wilson Lake and localities at similar range would have experienced the following: 1) thermal radiation within seconds and lasting the better part of an hour from a fireball sufficient to ignite trees; 2) seismic effects within around 4 minutes equivalent to a 9.7 Richter Scale Magnitude earthquake, which could have caused slumping on the continental margin and depressurized release of isotopically light methane hydrates (Katz et al., 1999), which may be needed to help drive the CIE and PETM (Gehler et al., 2016), and possibly even triggered an outburst of igneous activity (Richards et al., 2015) in the North Atlantic large igneous province (Svensen et al., 2004); 3) the arrival within 10 minutes of an ejecta blanket nearly $30 \mathrm{~mm}$ thick with mean fragment diameter of around $0.70 \mathrm{~mm}$; and importantly, 4) an air blast with wind velocities of $\sim 200 \mathrm{~m} / \mathrm{s}$ within about one hour that could have fanned the wildfires ignited initially by thermal radiation from the fireball. 


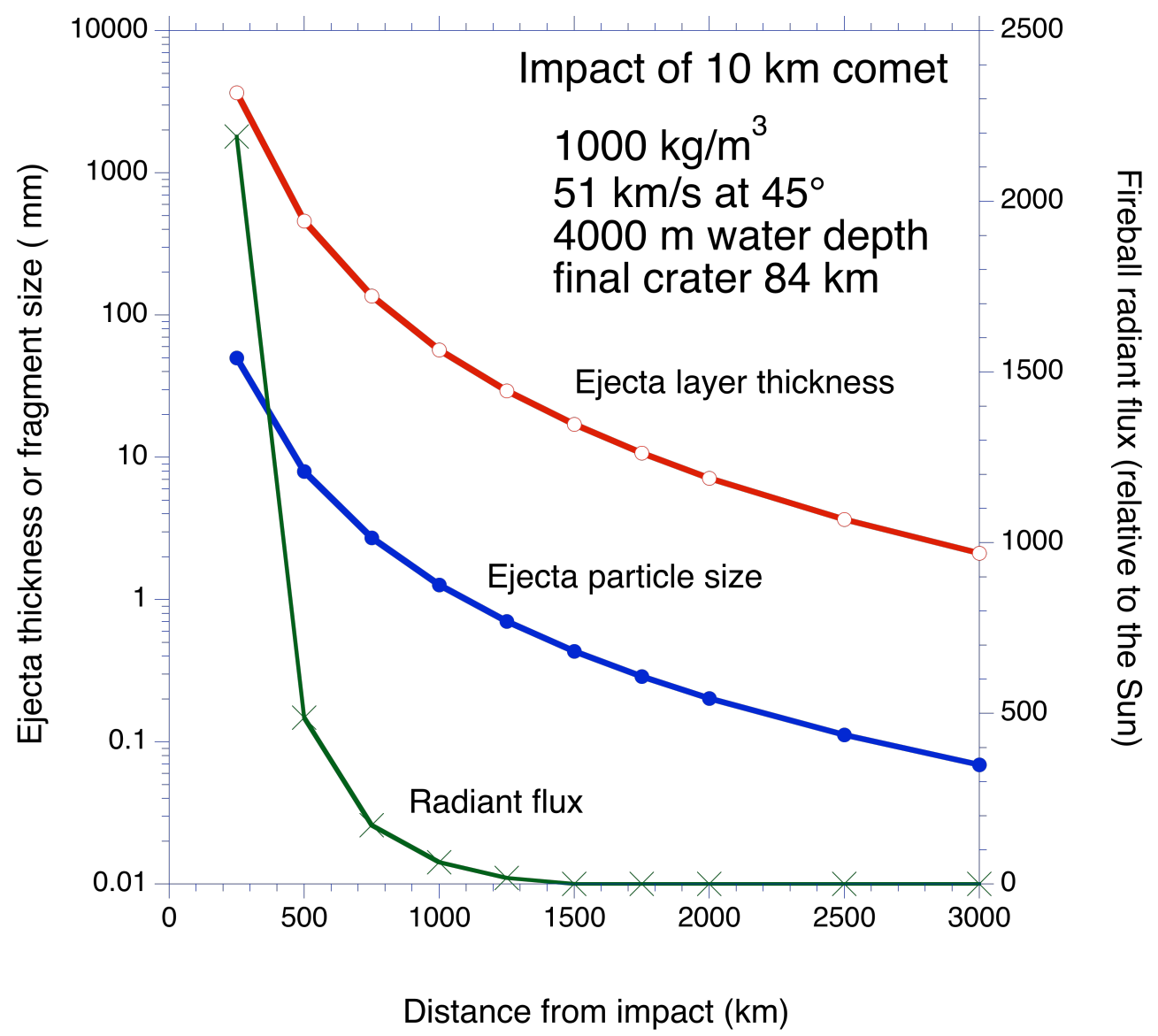

Figure S2. Impact effects as a function of distance from ground zero (Collins et al., 2005). 
Table S1. Magnetic hysteresis data for samples from Marlboro Clay and Vincentown Formation in Wilson Lake B core.

\begin{tabular}{|c|c|c|c|c|c|c|c|c|c|}
\hline $\begin{array}{c}\text { Sample } \\
\text { ID }\end{array}$ & $\begin{array}{l}\text { Depth } \\
\text { m }\end{array}$ & $\mathrm{M}_{\mathrm{r}} / \mathrm{M}_{\mathrm{s}}$ & $\mathrm{B}_{\mathrm{cr}} / \mathrm{B}_{\mathrm{c}}$ & $\begin{array}{c}\mathrm{M}_{\mathrm{r}} \\
\left(\mathrm{Am}^{2} / \mathrm{kg}\right)\end{array}$ & $\begin{array}{c}\mathrm{M}_{\mathrm{s}} \\
\left(\mathrm{Am}^{2} / \mathrm{kg}\right)\end{array}$ & $\begin{array}{l}\mathrm{B}_{\mathrm{cr}} \\
(\mathrm{T})\end{array}$ & $\begin{array}{l}\mathrm{B}_{\mathrm{c}} \\
(\mathrm{T})\end{array}$ & $\begin{array}{c}\chi_{\mathrm{HF}} \\
\left(10^{-6} \mathrm{~m}^{3} / \mathrm{kg}\right)\end{array}$ & f_SD \\
\hline \multicolumn{10}{|c|}{ Marlboro Clay } \\
\hline 341.1 & 103.97 & 0.41 & 1.72 & 0.0080 & 0.0196 & 0.044 & 0.026 & 0.1684 & 0.82 \\
\hline 342.0 & 104.24 & 0.39 & 1.72 & 0.0101 & 0.0257 & 0.045 & 0.026 & 0.1653 & 0.78 \\
\hline 343.5 & 104.70 & 0.40 & 1.68 & 0.0095 & 0.0235 & 0.042 & 0.025 & 0.1485 & 0.80 \\
\hline 344.5 & 105.00 & 0.39 & 1.74 & 0.0089 & 0.0227 & 0.042 & 0.024 & 0.1681 & 0.78 \\
\hline 344.5 & 105.00 & 0.39 & 1.75 & 0.0089 & 0.0227 & 0.042 & 0.024 & 0.1670 & 0.78 \\
\hline 345.5 & 105.31 & 0.3 & 2.00 & 0.0076 & 0.0252 & 0.045 & 0.022 & 0.20 & 0.58 \\
\hline 346.6 & 105.64 & 0.41 & 1.70 & 0.0106 & 0.0258 & 0.041 & 0.024 & 0.1493 & 0.82 \\
\hline 348.0 & 106.07 & 0.39 & 1.72 & 0.0123 & 0.0316 & 0.043 & 0.025 & 0.18 & 0.77 \\
\hline 349.5 & 106.53 & 0.35 & 1.78 & 0.0106 & 0.0306 & 0.042 & 0.024 & 0.1527 & 0.68 \\
\hline 350.5 & 106.83 & 0.33 & 1.84 & 0.0102 & 0.0310 & 0.043 & 0.023 & 0.1765 & 0.64 \\
\hline 352.1 & 107.32 & 0.38 & 1.74 & 0.0106 & 0.0283 & 0.040 & 0.023 & 0.1678 & 0.74 \\
\hline 353.0 & 107.59 & 0.35 & 1.76 & 0.0102 & 0.0288 & 0.040 & 0.023 & 0.1655 & 0.69 \\
\hline 354.1 & 107.93 & 0.25 & 1.81 & 0.0102 & 0.0411 & 0.036 & 0.020 & 0.1620 & 0.46 \\
\hline 355.0 & 108.20 & 0.37 & 1.77 & 0.0107 & 0.0289 & 0.037 & 0.021 & 0.1611 & 0.73 \\
\hline 356.2 & 108.57 & 0.35 & 1.73 & 0.0109 & 0.0316 & 0.036 & 0.021 & 0.2000 & 0.68 \\
\hline 361.0 & 110.03 & 0.36 & 1.82 & 0.0095 & 0.0260 & 0.039 & 0.022 & 0.1486 & 0.72 \\
\hline 362.2 & 110.40 & 0.37 & 1.79 & 0.0081 & 0.0218 & 0.040 & 0.023 & 0.1267 & 0.74 \\
\hline 363.6 & 110.83 & 0.36 & 1.69 & 0.0098 & 0.0276 & 0.048 & 0.028 & 0.1399 & 0.70 \\
\hline 364.2 & 111.01 & 0.35 & 1.70 & 0.0081 & 0.0231 & 0.050 & 0.030 & 0.1501 & 0.69 \\
\hline 364.5 & 111.10 & 0.23 & 1.86 & 0.0090 & 0.0385 & 0.052 & 0.028 & 0.1162 & 0.45 \\
\hline 364.9 & 111.22 & 0.25 & 1.83 & 0.0055 & 0.0221 & 0.051 & 0.028 & 0.1437 & 0.48 \\
\hline 365.5 & 111.40 & 0.19 & 2.21 & 0.0034 & 0.0183 & 0.055 & 0.025 & 0.1589 & 0.32 \\
\hline 365.7 & 111.47 & 0.20 & 2.39 & 0.0021 & 0.0103 & 0.053 & 0.022 & 0.1491 & 0.37 \\
\hline 365.9 & 111.53 & 0.09 & 3.87 & 0.0004 & 0.0047 & 0.053 & 0.014 & 0.1380 & 0.12 \\
\hline 366.3 & 111.65 & 0.15 & 2.59 & 0.0024 & 0.0163 & 0.043 & 0.017 & 0.1801 & 0.24 \\
\hline Average & $(n=25)$ & 0.32 & 1.93 & & 0.0250 & & 0.023 & & 0.62 \\
\hline StdDev & & 0.09 & 0.46 & 0.0031 & 0.0078 & 0.005 & 0.004 & 0.0204 & 0.20 \\
\hline \multicolumn{10}{|c|}{ Vincentown Formation } \\
\hline 367.3 & 111.95 & 0.05 & 8.60 & 0.0003 & 0.0062 & 0.030 & 0.004 & 96 & 0.02 \\
\hline 367.9 & 112.14 & 0.05 & 5.80 & 0.0002 & 0.0052 & 0.041 & 0.007 & 0.2181 & 0.02 \\
\hline 368.3 & 112.26 & 0.12 & 2.03 & 0.0012 & 0.0103 & 0.042 & 0.021 & 0.1813 & 0.17 \\
\hline 368.3 & 112.26 & 0.06 & 3.11 & 0.0013 & 0.0195 & 0.042 & 0.013 & 0.1689 & 0.06 \\
\hline 370.6 & 112.96 & 0.06 & 4.02 & 0.0007 & 0.0133 & 0.037 & 0.009 & 0.1191 & 0.04 \\
\hline 371.7 & 113.29 & 0.05 & 5.04 & 0.0005 & 0.0101 & 0.043 & 0.008 & 0.1218 & 0.02 \\
\hline AVeI age & $(n=6)$ & 0.07 & 4.77 & 0.0007 & 0.0108 & 0.039 & 0.010 & 0.1781 & 0.06 \\
\hline StdDev & & 0.03 & 2.31 & 0.0004 & 0.0052 & 0.005 & 0.006 & 0.0548 & 0.06 \\
\hline
\end{tabular}

Data were produced using a Micromag AGFM Model 2900 cycling to fields up to $1 \mathrm{~T}$ on sample chips of mass range $16-57 \mathrm{mg}$. Sample ID have prefix WLB and are denominated in driller's units (feet) corresponding to distance from the 
surface (Depth, converted to meters). $\mathrm{M}_{\mathrm{r}} / \mathrm{M}_{\mathrm{s}}$ is ratio of saturation remanence to saturation magnetization, $\mathrm{B}_{\mathrm{cr}} / \mathrm{B}_{\mathrm{c}}$ is ratio of remanent coercivity to coercivity. $\chi \mathrm{HF}$ is high field ( 0.3 to $1 \mathrm{~T})$ susceptibility, and $\mathrm{f}$ _SD is fraction of magnetization that is carried by single-domain particles using mixing curve \#3 (Dunlop, 2002), where the remanence ratio $\mathrm{M}_{\mathrm{r}} / \mathrm{M}_{\mathrm{s}}$ is modeled as a volume-weighted average:

$$
\mathrm{M}_{\mathrm{r}} / \mathrm{M}_{\mathrm{s}}=f \mathrm{SD}\left(\mathrm{M}_{\mathrm{r}} / \mathrm{M}_{\mathrm{s}}\right) \mathrm{SD}+f \mathrm{MD}\left(\mathrm{M}_{\mathrm{r}} / \mathrm{M}_{\mathrm{s}}\right) \mathrm{MD}
$$

We normalized the sum of $\mathrm{MD}$ and $\mathrm{SD}$ fractions to unity $(f \mathrm{MD}+f \mathrm{SD}=1)$ and used $\left(\mathrm{M}_{\mathrm{r}} / \mathrm{M}_{\mathrm{s}}\right) \mathrm{MD}=0.0375$ and $\left(\mathrm{M}_{\mathrm{r}} / \mathrm{M}_{\mathrm{s}}\right) \mathrm{SD}=0.493$ (Fig. 2 in Dunlop, 2002) to calculate:

$$
\begin{aligned}
f_{S D} & =-\frac{M_{r}-\left(M_{r} / M_{s}\right)_{M D} M_{S}}{M_{S}\left(\left(M_{r} / M_{s}\right)_{M D}-\left(M_{r} / M_{S}\right)_{S D}\right)}\left(M_{s} / M_{s a t}\right) \\
f_{M D} & =\frac{M_{r}-\left(M_{r} / M_{s}\right)_{S D} M_{S}}{M_{S}\left(\left(M_{r} / M_{s}\right)_{M D}-\left(M_{r} / M_{s}\right)_{S D}\right)}\left(M_{s} / M_{\text {sat }}\right)
\end{aligned}
$$

where $M_{r}$ and $M_{s}$ are the saturation remanence and saturation magnetization measured in the samples and $\mathrm{M}_{\text {sat }}$ is the saturation magnetization (a.k.a. spontaneous magnetization) of the pure magnetic mineral carrying the remanence in the samples (in this case, 92 $\mathrm{Am}^{2} / \mathrm{kg}$ for magnetite). Values of $\mathrm{M}_{\mathrm{s}}$ where obtained from hysteresis loops after removing the paramagnetic component of the induced magnetization by using the "approach to saturation" method described by Fabian (2006). $\chi_{\mathrm{HF}}$ is computed by measuring the induced magnetization above a field strength, $B$, that exceeds the saturation level of ferromagnetic minerals (in our case $300 \mathrm{mT}<\mathrm{B}<1 \mathrm{~T}$ ). The magnetization curve at $\mathrm{B}>300 \mathrm{mT}$ appears nearly rectilinear, indicative of the paramagnetic state of the mineral(s) involved, but to minimize bias from any higher coercivity phases, we again used the "approach to saturation" method (Fabian, 2006) in our computation of $\chi_{\mathrm{HF}}$. Negative diamagnetic susceptibility of probe paddle is several orders of magnitude smaller than clay samples and was ignored for calculating $\chi \mathrm{HF}$. An effort was made to orient the sample chips in the AGFM such that the applied field was in the horizontal (bedding) plane. 
Table S2. Bulk sediment ${ }^{87} \mathrm{Sr} /{ }^{86} \mathrm{Sr}$ ratios in samples across the contact between the Marlboro Clay and Vincentown Formation in Wilson Lake B core.

\begin{tabular}{|c|c|c|}
\hline $\begin{array}{c}\text { Sample } \\
\text { ID }\end{array}$ & $\begin{array}{l}\text { Depth } \\
\text { m }\end{array}$ & ${ }^{87} \mathrm{Sr} /{ }^{86} \mathrm{Sr}$ \\
\hline Marlboro & Clay & \\
\hline 321.0 & 97.84 & 0.74320 \\
\hline 330.0 & 100.58 & 0.74600 \\
\hline 340.0 & 103.63 & 0.74310 \\
\hline 350.0 & 106.68 & 0.74270 \\
\hline 360.0 & 109.73 & 0.73930 \\
\hline Average & $(n=5)$ & 0.74286 \\
\hline StdDev & & 0.00238 \\
\hline \multicolumn{3}{|c|}{ Vincentown Formation } \\
\hline 370.0 & 112.78 & 0.74200 \\
\hline 373.5 & 113.84 & 0.74225 \\
\hline 376.5 & 114.76 & 0.74207 \\
\hline 380.5 & 115.98 & 0.74404 \\
\hline 382.5 & 116.59 & 0.73546 \\
\hline 384.5 & 117.20 & 0.74317 \\
\hline Average & $(n=6)$ & 0.74150 \\
\hline StdDev & & 0.00306 \\
\hline
\end{tabular}

Sample ID have prefix WLB. About $50 \mathrm{mg}$ of powdered bulk sediment sample was weighed and dissolved in concentrated HF with several drops of concentrated $\mathrm{HNO}_{3}$ on a hot plate. The sample was dried down to a small droplet and re-dissolved in $0.2 \mathrm{ml}$ of $2 \mathrm{~N}$ $\mathrm{HNO}_{3}$. Strontium was separated by column chemistry using Sr SPEC Resin. The collected $\mathrm{Sr}$ was dried and re-dissolved in $2 \mathrm{ml} \mathrm{2 \%} \mathrm{HNO}_{3}$ (trace of $\mathrm{HF}$ ). A split of the sample was diluted to $4 \mathrm{ml}$ in $2 \%$ nitric acid (trace of HF) to produce about 10-20 v on mass 88. Mass Sr84, 86, 87, 88, Rb85, Kr82, and 83 were collected by MC-ICP-MS on the Neptune Plus (EPS Rutgers University) in static collection mode. Mass bias was corrected by normalization to ${ }^{88} \mathrm{Sr} /{ }^{86} \mathrm{Sr}$, and $\mathrm{Kr}$ interferences $(<0.1 \mathrm{mV})$ were subtracted from ${ }^{86} \mathrm{Sr}$. Four Standard Reference Material (SRM) 987 measurements were made with the samples, yielding a mean value of $0.710242 \pm 0.000031(2 \sigma)$ compared to $0.710255 \pm 0.000024$ for Sr-isotope measurements using multi-collector inductively coupled plasma mass spectrometry (Waight et al., 2002). 
Table S3. Recent determinations of carbon isotopic composition of various comets.

\begin{tabular}{|c|c|c|}
\hline$\# \quad \delta^{13} \mathrm{C}^{*}$ & ${ }^{12} \mathrm{C} /{ }^{13} \mathrm{C}$ & Species \\
\hline
\end{tabular}

\begin{tabular}{lrrlcll}
\hline 1 & -45 & 93 & \pm 10 & ${ }^{12} \mathrm{C} /{ }^{13} \mathrm{C}$ & 4 OCC & Optical spectra \\
2 & -11 & 90 & \pm 10 & ${ }^{13} \mathrm{CN}$ & Halley + 3 OPP & Optical spectra \\
$3 \mathrm{a}$ & -247 & 111 & \pm 12 & $\mathrm{H}^{13} \mathrm{CN}$ & Hale-Bopp & Radio spectra \\
$3 \mathrm{~b}$ & -225 & 109 & \pm 22 & & & \\
4 & -11 & 90 & \pm 20 & ${ }^{13} \mathrm{CN}$ & Hale-Bopp & Optical spectra \\
5 & -1 & $89.1 \pm 4.2$ & ${ }^{13} \mathrm{CN}$ & 14 OCC & Optical spectra \\
6 & -92 & $97.2 \pm 7.6$ & ${ }^{13} \mathrm{CN}$ & 4 JFC & Optical spectra \\
7 & -56 & 94 & \pm 8 & $\mathrm{H}^{13} \mathrm{CN}$ & Hale-Bopp & Radio spectra \\
8 & -281 & 114 & \pm 26 & $\mathrm{H}^{13} \mathrm{CN}$ & 17P/Holmes & Radio spectra \\
9 & -11 & 90 & \pm 20 & ${ }^{13} \mathrm{CN}$ & 17P/Holmes & Optical spectra \\
10 & -11 to -56 & {$[90-94]$} & ${ }^{13} \mathrm{C}-$ & $81 \mathrm{P} /$ Wild2 & Laboratory NanoSIMS \\
& & & & & \\
\hline
\end{tabular}

*Assuming that zero in the scale corresponds to ${ }^{12} \mathrm{C}$ to ${ }^{13} \mathrm{C}$ ratio of 89 for PDB (Craig, 1957). Median value for items $\# 1-9$ is $-51 \%$ o $\delta^{13} \mathrm{C}$ or $93.5^{12} \mathrm{C} /{ }^{13} \mathrm{C}$, within the range of direct measurements of dust particles from 81P/Wild2 (item \#10). From Table 1 of Jehin et al. (2009), which has the references for each item. 


\section{Supplemental Material references}

Clement, B.M., Javier, J., Sah, J.P., Ross, M.S., 2011. The effects of wildfires on the magnetic properties of soils in the Everglades. Earth Surface Processes and Landforms 36, 460-466.

Collins, G.S., Melosh, H.J., Marcus, R.A., 2005. Earth Impact Effects Program: A Webbased computer program for calculating the regional environmental consequences of a meteoroid impact on Earth. Meteoritics \& Planetary Science 40, 817-840.

Collinson, M.E., Hooker, J.J., Gröcke, D.R., 2003. Cobham Lignite Bed and penecontemporaneous macrofloras of southern England: A record of vegetation and fire across the Paleocene-Eocene Thermal Maximum. Geological Society of America Special Paper 369, 335-350.

Craig, H., 1957. Isotopic standards for carbon and oxygen and correction factors for mass-spectrometric analysis of carbon dioxide. Geochimica et Cosmochimica Acta 12, 133-149.

Delsemme, A.H., 1988. The chemistry of comets. Philosophical Transactions of the Royal Society of London A325, 509-523.

Dunlop, D.J., 2002. Theory and application of the Day plot (Mrs/Ms versus Hcr/Hc) 2 . Application to data for rocks, sediments, and soils. Journal of Geophysical Research 107, doi:10.129/2001JB000487.

Fabian, K., 2006. Approach to saturation analysis of hysteresis measurements in rock magnetism and evidence for stress dominated magnetic anisotropy in young midocean ridge basalt. Physics of the Earth and Planetary Interiors 154, 299-307.

Farouki, O.T., 1981. Thermal properties of soils, in: Engineers, U.S.A.C.o. (Ed.). Cold Regions Research and Engineering Laboratory Monograph 81-1, Hanover, New Hampshire, USA, p. 136.

Gehler, A., Gingerich, P.D., Pack, A., 2016. Temperature and atmospheric CO2 concentration estimates through the PETM using triple oxygen isotope analysis of mammalian bioapatite. Proceedings of the National Academy of Sciences 113, 77397744.

Giovannini, G., Lucchesi, S., M., G., 1988. Effects of heating on some physical and chemical parameters related to soil aggregation and erodibility. Soil Science 146, 255261.

Greenberg, J.M., 1998. Making a comet nucleus. Astronomy and Astrophysics 330, 375380.

Humphreys, G.S., Shakesby, R.A., Doerr, S.H., Blake, W.H., Wallbrink, P., Hart, D.M., 2003. Some effects of fire on the regolith, in: Roach, I.C. (Ed.), Advances in Regolith. CRC LEME, pp. 216-220.

Jehin, E., Manfroid, J., Hutsemékers, D., Arpigny, C., Zucconi, J.-M., 2009. Isotopic Ratios in Comets: Status and Perspectives. Earth, Moon and Planets 105, 167-180.

Katz, M.E., Pak, D.K., Dickens, G.R., Miller, K.G., 1999. The source and fate of massive carbon input during the latest Paleocene thermal maximum. Science 286, 1531-1533.

Kopp, R.E., Schumann, D., Raub, T.D., Powars, D.S., Godfrey, L.V., Swanson-Hysell, N.L., Maloof, A.C., Vali, H., 2009. An Appalachian Amazon? Magnetofossil evidence for the development of a tropical river-like system in the mid-Atlantic United States 
during the Paleocene-Eocene thermal maximum. Paleoceanography 24, PA4211, doi:4210.1029/2009PA001783.

Le Borgne, E., 1960. Influence du feu sur les propriétés magnétiques du sol et sur celles du schiste et du granite. Annales de Geophysique 16, 159-195.

Marlon, J.R., Bartlein, P.J., Walsh, M.K., Harrison, S.P., Brown, K.J., Edwards, M.E., Higuera, P.E., Power, M.J., Anderson, R.S., Briles, C., Brunelle, A., Carcaillet, C., Daniels, M., Hu, F.S., Lavoie, M., Long, C., Minckley, T., Richard, P.J.H., Scott, A.C., Shafer, D.S., Tinner, W., Umbanhowar, C.E., Whitlock, C., 2009. Wildfire responses to abrupt climate change in North America. Proceedings of the National Academy of Sciences 106, 2519-2524.

Messenger, S., 2000. Identification of molecular-cloud material in interplanetary dust particles. Nature 404, 968-971.

Molina, M.J., Llinares, J.V., 2001. Temperature-time curves at the soil surface in maquis summer fires. International Journal of Wildland Fire 10, 45-52.

Mumma, M.J., Charnley, S.B., 2011. The Chemical Composition of Comets-Emerging Taxonomies and Natal Heritage. Annual Review of Astronomy and Astrophysic 49, 471-524.

Pazzaglia, F.J., Brandon, M.T., 1996. Macrogeomorphic evolution of the post-Triassic Appalachian mountains determined by deconvolution of the offshore basin sedimentary record. Basin Research 8, 255-278.

Richards, M.A., Alvarez, W., Self, S., Karlstrom, L., Renne, P.R., Manga, M., Sprain, C.J., Smit, J., Vanderkluysen, L., Gibson, S.A., 2015. Triggering of the largest Deccan eruptions by the Chicxulub impact. Geological Society of America Bulletin 127, 15071520.

Rummery, T., 1983. The use of magnetic measurements in interpreting the fire histories of lake drainage basins. Hydrobiologia 103, 53-58.

Santín, C., Doerr, S.H., Merino, A., Bryant, R., Loader, N.J., 2016. Forest floor chemical transformations in a boreal forest fire and their correlations with temperature and heating duration. Geoderma 264, Part A, 71-80.

Schmitz, B., Asaro, F., Molina, E., Monechi, S., von Salis, K., Speijer, R.P., 1997. Highresolution iridium, $\delta^{13} \mathrm{C}, \delta^{18} \mathrm{O}$, foraminifera and nannofossil profiles across the latest Paleocene benthic extinction event at Zumaya, Spain. Palaeogeography, Palaeoclimatology, Palaeoecology 133, 49-68.

Schmitz, B., Peucker-Ehrenbrin, B., Heilmann-Clausen, C., Aberg, G., Asaro, F., Lee, C.T.A., 2004. Basaltic explosive volcanism, but no comet impact, at the PaleoceneEocene boundary: high-resolution chemical and isotopic records from Egypt, Spain and Denmark. Earth and Planetary Science Letters 225, 1-17.

Svensen, H., Planke, S., Malthe-Sørenssen, A., Jamtveit, B., Myklebust, R., Eidem, T.R., Rey, S.S., 2004. Release of methane from a volcanic basin as a mechanism for initial Eocene global warming. Nature 429, 542-545.

Waight, T.E., Baker, J.A., Peate, D.W., 2002. Sr isotope ratio measurements by doublefocusing MC-ICPMS: techniques, observations and pitfalls. International Journal of Mass Spectrometry 221, 229-244.

Wing, S.L., Currano, E.D., 2013. Plant response to a global greenhouse event 56 million years ago. American Journal of Botany 100, 1234-1254. 